\title{
Utility of antioxidants during assisted reproductive techniques: an evidence based review
}

\author{
Ashok Agarwal $^{1 *}$, Damayanthi Durairajanayagam ${ }^{2}$ and Stefan S du Plessis ${ }^{1,3}$
}

\begin{abstract}
Assisted reproductive technology (ART) is a common treatment of choice for many couples facing infertility issues, be it due to male or female factor, or idiopathic. Employment of ART techniques, however, come with its own challenges as the in vitro environment is not nearly as ideal as the in vivo environment, where reactive oxygen species (ROS) build-up leading to oxidative stress is kept in check by the endogenous antioxidants system. While physiological amounts of ROS are necessary for normal reproductive function in vivo, in vitro manipulation of gametes and embryos exposes these cells to excessive ROS production either by endogenous or exogenous environmental factors. In this review, we discuss the sources of ROS in an in vitro clinical setting and the influence of oxidative stress on gamete/embryo quality and the outcome of IVF/ICSI. Sources of ROS and different strategies of overcoming the excessive generation of ROS in vitro are also highlighted. Endogenously, the gametes and the developing embryo become sources of ROS. Multiple exogenous factors act as potential sources of ROS, including exposure to visible light, composition of culture media, $\mathrm{pH}$ and temperature, oxygen concentration, centrifugation during spermatozoa preparation, ART technique involving handling of gamete/embryo and cryopreservation technique (freeze/thawing process). Finally, the use of antioxidants as agents to minimize ROS generation in the in vitro environment and as oral therapy is highlighted. Both enzymatic and non-enzymatic antioxidants are discussed and the outcome of studies using these antioxidants as oral therapy in the male or female or its use in vitro in media is presented. While results of studies using certain antioxidant agents are promising, the current body of evidence as a whole suggests the need for further well-designed and larger scale randomized controlled studies, as well as research to minimize oxidative stress conditions in the clinical ART setting.
\end{abstract}

Keywords: Reactive oxygen species, Oxidative stress, Antioxidants, Assisted reproductive technology, In vitro fertilization, Intracytoplasmic sperm injection, ART outcome

\section{Background}

Infertility, a disease of the reproductive system defined by the failure to achieve a clinical pregnancy after 12 months or more of regular unprotected sexual intercourse [1], affects $15 \%$ of all couples, with nearly a quarter of cases being without an identifiable causative factor [2]. Medical treatment for infertility include in vitro fertilization (IVF) and intracytoplasmic sperm injection (ICSI), which are the two most common interventions used in assisted reproductive technology (ART) [3].

Successful ART outcome, including fertilization and clinical pregnancy resulting in live birth, is influenced by

\footnotetext{
*Correspondence: agarwaa@ccf.org

${ }^{1}$ Center for Reproductive Medicine, Glickman Urological \& Kidney Institute, Cleveland Clinic, Cleveland, OH 44195, USA

Full list of author information is available at the end of the article
}

a multitude of factors - among which reactive oxygen species (ROS) plays a significant role [4]. The consequent development of oxidative stress is among the chief causes of defective gametes or poorly-developing embryos in ART [5]. This occurs because the IVF process performed in a clinical laboratory setting cannot recreate the exact conditions under which natural fertilization takes place [6]. Among the crucial factors lacking in assisted reproduction procedures is the tight control of ROS levels maintained within physiological concentration by antioxidants in vivo [3].

In order to optimize gamete/embryo quality and improve ART outcome, deliberate preventive measures are necessary to reduce any incidental build-up of ROS leading to oxidative stress development during ART. One method to achieve this would be by enhancing the antioxidant 
capacity of the gamete and embryo against the harmful assault of oxidation. In this paper, we will review the sources of oxidative stress and the use of antioxidants in a clinical ART setting to minimize the detrimental effects of oxidative stress on gamete and/or embryo during assisted reproduction.

\section{Free radicals, reactive oxygen species and oxidative stress}

Free radicals are molecules or atoms with an odd or unpaired number of valence electrons. Although necessary for physiological bodily functions, free radicals are harmful in larger amounts and are involved in the pathophysiology of various diseases [6]. Free radicals are extremely reactive and participate in chain reactions that cause other molecules to become unstable, which generate even more free radicals [5].

ROS comprise both free radical and non-free radical oxygen-derived reactive molecules. ROS are constantly generated, as part of normal aerobic life, during the intermediate steps of oxygen reduction along the mitochondrial electron transport chain [7]. Formation of ROS also occurs as necessary intermediates during various enzymatic reactions. Common forms of ROS include superoxide anion radical $\left(\mathrm{O}_{2}^{*-}\right)$, hydroxyl radical $\left({ }^{\circ} \mathrm{OH}\right)$, hydrogen peroxide $\left(\mathrm{H}_{2} \mathrm{O}_{2}\right)$ and singlet oxygen $\left({ }^{1} \mathrm{O}_{2}\right)$. Reactive nitrogen species (a subset of ROS) include nitric oxide $\left(\mathrm{NO}^{\circ}\right)$ and the peroxynitrite anion $\left(\mathrm{ONOO}^{-}\right)$[8]. ROS in high concentrations cause cellular toxicity and can impair the spermatozoon's ability to fertilize the oocyte [9]. However, small amounts of ROS are required for the regulation of various gamete functions $[10,11]$.

Oxidative stress develops upon an imbalance between systemic production of ROS and the ability to either readily detoxify ROS (antioxidant defenses) or repair the ensuing damage resulting from lipid peroxidation, DNA damage and apoptosis [12]. Prevention of oxidative stress is vital in order to maintain normal reproductive function [13]. Both male and female reproductive systems possess antioxidant defense mechanisms that facilitate the quenching of ROS, and maintain equilibrium between pro- and anti-oxidants. This confers protection from oxidative damage to the gonadal cells and gametes, which is vital in the upkeep of normal reproductive function.

\section{Oxidative stress in the ART setting}

Despite the advancement of ART techniques, gametes and embryos when handled, prepared and manipulated for ART procedures, are exposed to various potential ROS-inducing factors. In vitro, the risk of oxidative stress development is greater than in vivo [13] and its negative impact may be amplified due to the lack of physiological defense mechanisms, absence of natural antioxidants and the presence of multiple potential sources of ROS [4]. These sources of ROS during ART procedures could either be endogenously from gametes or via exogenous environmental factors [5]. However, unless measures are taken to curb ROS production, both the endogenous and exogenous sources of ROS will ultimately lead to the development of oxidative stress, which would then negatively impact on fertilization rates and pregnancy outcome.

\section{Sources of ROS \\ In vivo}

Spermatozoa, oocytes and embryos rely on mitochondrial oxidative phosphorylation for energy, a process which is subsequently accompanied by ROS generation [5].

Originating from the male Normal human spermatozoa function such as maturation, capacitation, hyperactivation, acrosome reaction and oocyte fusion are facilitated by physiological levels of ROS [14]. However, excess ROS is detrimental to the spermatozoa functionality and could lead to male infertility [15]. In human semen, immature spermatozoa and leukocytes are the two main endogenous potential sources of ROS [16]. Spermatozoa are particularly susceptible to oxidative stress as its cell membranes are rich in polyunsaturated fatty acids, making it more vulnerable to oxygen-induced damage and lipid peroxidation. Furthermore, mature spermatozoa lack cytoplasmic enzymes and antioxidant defense mechanisms [17].

Immature spermatozoa During spermatogenesis damaged spermatozoa undergo arrested spermiogenesis. This causes them to maintain excess residual cytoplasm, which can activate the NADPH system. As such, spermatozoa with cytoplasmic droplets act as a potential contributor to ROS production [18]. Immature spermatozoa with excess cytoplasm around its midpiece are functionally defective having impaired motility and abnormal morphology, which impacts negatively on its fertilization potential [19].

Leukocytes Leukocytes are the predominant source of ROS during spermatozoa preparation, as they are able to produce up to 1000 times more ROS than spermatozoa in human semen [20,21]. Originating from the prostate gland and seminal vesicles, peroxidase-positive leukocytes include polymorphonuclear leukocytes and macrophages [22]. During infection or inflammation processes in vivo, leukocytes release large amounts of superoxide when conquering pathogens [4]. Seminal leukocytes also stimulate spermatozoa to produce ROS [3].

Varicocele Varicocele is the abnormal dilatation of veins in the pampiniform plexus surrounding the spermatic cord. It is believed to be the most common and treatable cause of male factor infertility, however a recent Cochrane 
review suggests that these assumptions are inconclusive as the quality of the available evidence is very low [23]. Varicocele of a higher grade is associated with greater amounts of seminal ROS [24]. Infertile men with varicocele have increased oxidative stress levels and lowered antioxidant concentrations [25].

Originating from the female Physiological levels of ROS are likely to play a role in several aspects of female reproduction including ovarian steroidogenesis, oocyte maturation, folliculogenesis, ovulation and luteolysis [26,27].

Oocyte Oocyte quality is correlated with 8-hydroxy-2'deoxyguanosine (8-OHdG) (a biomarker of oxidative stress induced-DNA damage) levels in granulosa cells [28]. Poor oocyte quality would lead to compromised embryo development. In the oocyte, ROS levels when present in excess, can disrupt the oocyte cytoskeleton, alter microtubule function, cause chromosomal scattering and aneuploidy [5]. These effects could negatively impair ART outcome.

Cumulus mass cells Cumulus cells originate from relatively undifferentiated granulosa cells. The cumulus oophorus encircles the oocyte and is made up of the cumulus cells and extracellular matrix [29]. Cumulus cells closely interact and provide support to the developing and maturing oocyte, shares the oocyte's microenvironment and minimize damage by ROS. Cumulus cells are able to produce antioxidants, such as superoxide dismutase (SOD), which are suggested to protect the oocyte from ROS-induced damage [30]. Higher SOD levels in cumulus cells are associated with ART outcome success [31]. Increased levels of 8-OHdG (an oxidative stress by-product) in cumulus cells yielded lower oocyte fertilization rates and poorer embryo quality [28].

Follicular fluid Follicular fluid is secreted by the follicular theca and granulosa cells, and fills the antral follicle. Low levels of follicular fluid ROS may be used to predict potential success of IVF [32,33]. Pregnancy outcome after ICSI is negatively associated with high levels of follicular fluid ROS, but is positively associated with follicular fluid total antioxidant capacity [34]. The ROS upper reference limit above which viable embryo formation became unsatisfactory was calculated to be around $107 \mathrm{cps} / 400 \mu \mathrm{l}$ follicular fluid in women with tubal factor infertility, endometriosis and polycystic ovarian syndrome (PCOS). Not only was fertilization rate and percentage of grades I and II embryo formation higher in those patients with follicular fluid ROS levels less than the set limit, when compared to those above the limit, but DNA fragmented embryos were also significantly lower [35]. As such, the ROS level in follicular fluid seems to provide an indication of embryo formation and quality [36].
Originating from the embryo The fast developing embryo produces energy via ATP generation through mitochondrial oxidative phosphorylation and glycolysis. As it develops, the embryo is capable of producing ROS through several pathways, namely oxidative phosphorylation, NADPH and xanthine oxidase systems [37]. ROS generation is particularly excessive during embryonic genome activation, embryonic compaction and hatching as these processes demand greater amounts of energy [38]. Conversely, embryos exposed to high ROS levels are of lower quality and run the risk of early embryonic developmental block and retardation [39]. Although ROS production was reportedly greater in embryos cultured in vitro compared to those developing in vivo [40], it remains uncertain if and how much the ART procedure itself (techniques and conditions employed) contributed to the higher levels of oxidative stress [5].

\section{In vitro}

Figure 1 depicts the potential sources of ROS and oxidative stress in vitro in a typical clinical ART setting.

Visible light In vitro handling of gametes and embryos involves the inevitable exposure to visible light (400-700 $\mathrm{nm}$ ), from both microscope and from ambient lighting (laboratory/fluorescent light and daylight/indirect sunlight) $[41,42]$. Light within the visible spectrum (visible light) has detrimental effects on gametes and developing embryo. The negative impact of visible light is influenced by duration of exposure, intensity and spectral composition of light [42].

Blue light (400-500 nm) is particularly more damaging than visible light with longer wavelengths, as blue light could generate hydrogen peroxide and alter enzymes in the respiratory chain $[43,44]$. Mouse embryo exposed to blue light had reduced blastocyst formation rates, higher blastomeric apoptosis rates and higher ROS production in morula [45]. The use of light filters on inspection microscopes (which cuts off light $<500 \mathrm{~nm}$ ) $[42,46]$, illumination levels kept at a minimum without compromising visual inspection and shorter inspection time could help curb these effects [42].

Light exposure is measured as units of illumination intensity (lux) or by the level of irradiation $\left(\mathrm{W} / \mathrm{m}^{2}\right)$. Using low illumination levels (100 lux from microscope, 20 lux from ceiling) during human embryo manipulation throughout in vitro fertilization-embryo transfer (IVF-ET) procedures (and other measures to minimize oxidative stress development in vitro) in 110 IVF cycles yielded a relatively high blastulation rate [46].

In a recent in vitro study, porcine parthenogeneticallyactivated embryos that were developed in culture medium with prior $24 \mathrm{~h}$-exposure to ambient light yielded a higher percentage of blastocysts with poor morphology 


\section{Effects of Oxidative Stress (OS) and Interventions to Overcome its Effects at Different ART Steps}

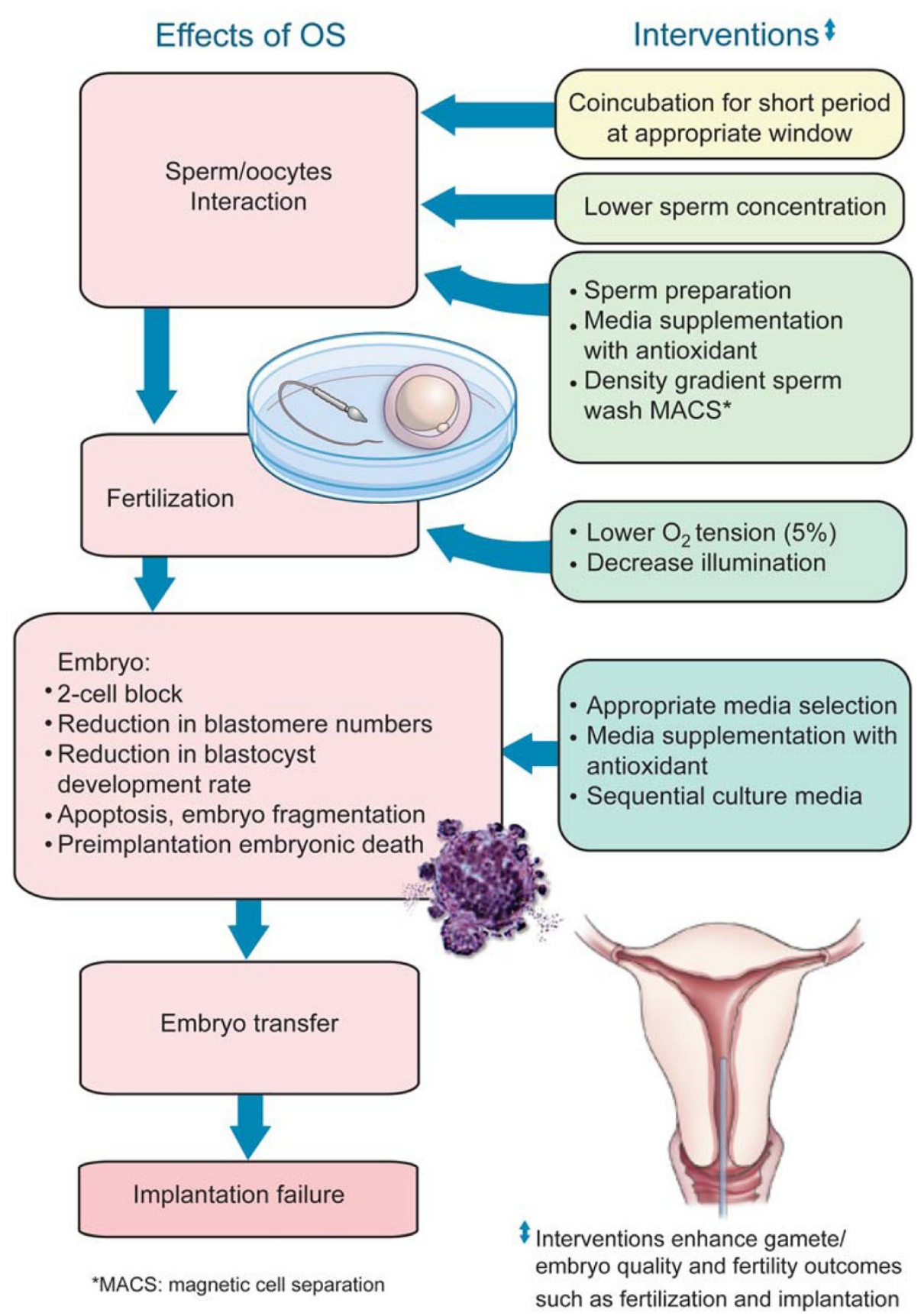

Figure 1 Potential sources of oxidative stress in vitro in a typical clinical ART setting. In a typical ART setting, the potential sources of oxidative stress in vitro include endogenous and exogenous (external/environmental factors). The gametes and pre-implantation embryo have the potential to generate ROS (endogenous sources). Exogenous factors such as visible light; centrifugation, cryopreservation (freeze/thawing), culture media; oxygen concentration, $\mathrm{pH}$ and temperature; and the in vitro fertilization-embryo transfer technique/process itself contributes to ROS production during ART. 
[41]. Further, activated-oocytes that had prior $1 \mathrm{~h}$-exposure to ambient light formed fewer and lower quality blastocysts. This detrimental effect of light exposure on blastocysts was found to increase with time [41]. Several other studies have documented the negative impact of visible light exposure on animal embryo development [43,47-50].

Light irradiation $\left(40 \mathrm{~mW} / \mathrm{cm}^{2}\right.$ visible light or 400 to $800 \mathrm{~nm}$ with maximum energy at $600 \mathrm{~nm}$ for 3 minutes) of human spermatozoa in capacitation media increased hyper-activated motility, without enhancing total motility [51]. As hyper-activated motility escalates the swimming speed of spermatozoa and helps produce adequate penetration force [52], development of hyper-activated motility during the spermatozoa capacitation process may be critical to ensure successful fertilization [53]. However, production of ROS in these spermatozoa increased upon 1 to 3 minutes of light exposure [51].

Culture media The composition of media used during the culture of human oocytes and pre-implantation embryos has a direct influence on embryo quality and subsequently ART success [11]. Presence of metallic ions (iron, $\mathrm{Fe}^{2+}$ and copper, $\mathrm{Cu}^{2+}$ ) in culture media could trigger ROS-generating reactions within the cells [37], and the rate of ROS formation varies with the composition of culture media [35]. Addition of metal chelators (e.g. EDTA) may reduce ROS formation [54,55], however, additional supplements (e.g. albumin) may instead cause a build-up of oxygen load [5]. Supplementation of culture media with antioxidants (e.g. ascorbic acid, alphatocopherol) could help alleviate the adverse effects of ROS on gametes [56]. Key findings of studies using antioxidants in vitro in media are summarized in Table 1.

pH and temperature Intracellular homeostasis is highly susceptible to changes in $\mathrm{pH}$ (most occur within a $\mathrm{pH}$ of 6 to 8), especially key processes such as protein synthesis, mitochondrial function, cytoskeletal regulation and cellular metabolism [68]. Fluctuations of hydrogen ion concentration $(\mathrm{pH})$ in culture media could negatively impact spermatozoa motility, oocyte maturation and embryo development $[68,69]$. Thus, to maintain the $\mathrm{pH}$ of culture media, incubator $\mathrm{CO}_{2}$ levels should be kept stable, as low $\mathrm{CO}_{2}$ levels tend to increase the $\mathrm{pH}$ of culture media [68]. Increases in $\mathrm{pH}$ could subject cells to oxidative stress conditions.

The use of buffers in media helps with $\mathrm{pH}$ maintenance, such as sodium bicarbonate during IVF procedures, and HEPES buffer for storage and handling of spermatozoa [68]. In case of room temperature-procedures such as collection of gamete, cryopreservation, ICSI and embryo transfer, external $\mathrm{pH}$ outside of the incubator is maintained by including another $\mathrm{pH}$ buffer along with handling media containing lower bicarbonate levels [68].
Incubator temperature should also be constantly maintained at human body temperature [70], as increasing temperatures decrease $\mathrm{pH}$ and $\mathrm{pK}_{\mathrm{a}}$ levels [71], disrupt intracellular processes and may further cause ROS-induced cellular damage [72].

Oxygen concentration During IVF and ICSI, preimplantation embryos are cultured in the ART laboratory, commonly under the oxygen concentration of either atmospheric $(\sim 20 \%)$ or low $(\sim 5 \%)$ oxygen concentrations in vitro [73]. Compared to atmospheric ( 20\%) oxygen concentrations, embryo culture in lower $(\sim 5 \%)$ oxygen concentrations closer resembled physiological oxygen concentration in the oviduct and uterus ( $2 \%$ to $8 \%)$ [73]. Hyperoxic conditions could enhance the activity of oxygen-dependent oxidase enzymes [37]. Thus, oxygen concentrations at atmospheric levels could generate ROS and cause the development of oxidative stress [74], thus negatively impacting embryo quality.

A Cochrane systematic review (7 studies, 2422 participants) and meta-analysis (4 studies, 1382 participants) reported that embryos developed better and were of higher quality when cultured in low (5\%) oxygen concentrations, leading to improved ongoing and clinical pregnancy rates, and live birth rates. Thus, embryo culture in low $(\sim 5 \%)$ oxygen concentrations improves IVF/ICSI success rates and results in the birth of healthier babies [75]. Even among poor responders of IVF and ICSI cycles, embryos developed at low (5\%) oxygen concentrations resulted in higher pregnancy rates [76,77].

In an earlier meta-analysis of 7 randomized controlled trials (RCTs) comparing the effects of oocyte/embryo culture at low $(\sim 5 \%)$ and atmospheric ( $20 \%)$ oxygen concentrations, embryos transferred on days 2 or 3 had similar implantation rates while embryos transferred on days 5 or 6 (blastocyst stage) had significantly higher implantation rates when cultured in 5\% oxygen concentration. However, in this study, ongoing pregnancy rates were similar regardless of the oxygen concentration $(\sim 5 \%$ or $\sim 20 \%$ ) or day of transfer (days $2 / 3$ or days $5 / 6$ ) [78].

Centrifugation In ART, centrifugation is a routine step used in spermatozoa preparation techniques to remove seminal plasma, which is a potential source of ROS [79]. However, the centrifugation process itself contributes to ROS levels, with the length of centrifugation time having a greater influence in inducing-ROS formation compared to the g-force applied [79]. Despite the initial spermatozoa quality, longer time of centrifugation exposes spermatozoa to higher temperature and causes greater detriment to sperm parameters [80]. Thus, during spermatozoa preparation protocols, addition of antioxidants such as pentoxifylline [81] in advance of the centrifugation step, could reduce 
Table 1 Study outcomes involving in vitro supplementation of various antioxidants during ART protocol

\begin{tabular}{|c|c|c|c|c|c|c|}
\hline Antioxidant & Study type & $\begin{array}{l}\text { Patient } \\
\text { population }\end{array}$ & $\begin{array}{l}\text { Intervention } \\
\text { (therapeutic } \\
\text { approach) }\end{array}$ & $\begin{array}{l}\text { Control group } \\
\text { (daily dose) }\end{array}$ & $\begin{array}{l}\text { Outcome/effect of } \\
\text { intervention/effect } \\
\text { on parameters }\end{array}$ & Reference \\
\hline \multirow[t]{2}{*}{ Vitamin E } & \multirow[t]{2}{*}{ Prospective } & \multirow{2}{*}{$\begin{array}{l}\text { Sperm from } \\
\text { normozoospermic } \\
\text { and asthenozoospermic } \\
\text { men }\end{array}$} & \multirow{2}{*}{$\begin{array}{l}5 \mathrm{mM} \text { vitamin } \mathrm{E} \\
\text { added to } \\
\text { cryoprotective } \\
\text { media prior to } \\
\text { freeze-thaw } \\
\text { procedure }\end{array}$} & & $\begin{array}{l}\text { 1. Improvement } \\
\text { in post-thaw motility }\end{array}$ & \multirow[t]{2}{*}{$\begin{array}{l}\text { Kalthur et al. } \\
\text { [57] }\end{array}$} \\
\hline & & & & & $\begin{array}{l}\text { 2. Improvement in } \\
\text { DNA integrity }\end{array}$ & \\
\hline Vitamin E & Prospective & $\begin{array}{l}\text { Sperm from } \\
\text { normozoospermic } \\
\text { men and men } \\
\text { with abnormal } \\
\text { sperm parameters }\end{array}$ & $\begin{array}{l}100 \mu \mathrm{mol} \text { or } 200 \mu \mathrm{mol} \\
\text { vitamin } \mathrm{E} \text { added to } \\
\text { cryopreservation media }\end{array}$ & & $\begin{array}{l}\text { Improved post-thaw } \\
\text { motility of cryopreserved } \\
\text { sperm from men with } \\
\text { both normal and abnormal } \\
\text { sperm parameters }\end{array}$ & $\begin{array}{l}\text { Taylor et al. } \\
\text { [58] }\end{array}$ \\
\hline \multirow{2}{*}{$\begin{array}{l}\text { Vitamin E } \\
\text { (alpha- } \\
\text { tocopherol) }\end{array}$} & \multirow[t]{2}{*}{ Prospective } & \multirow{2}{*}{$\begin{array}{l}\text { Sperm from } \\
\text { teratozoospermic } \\
\text { men }(n=15)\end{array}$} & \multirow{2}{*}{$\begin{array}{l}\text { Sperm prepared by } \\
\text { swim up incubated } \\
\text { with } 40 \mu \mathrm{mol} \\
\text { alpha-tocopherol } \\
\text { added to media x } \\
1 \text { hour }\end{array}$} & & 1. Improved sperm motility & \multirow{2}{*}{$\begin{array}{l}\text { Keshtgar et al. } \\
\text { [59] }\end{array}$} \\
\hline & & & & & 2. Increased sperm viability & \\
\hline \multirow[t]{4}{*}{ Vitamin C } & \multirow[t]{4}{*}{ Prospective } & \multirow{4}{*}{$\begin{array}{l}\text { Sperm from male } \\
\text { volunteers with } \\
\text { teratozoospermia } \\
(n=15)\end{array}$} & \multirow{4}{*}{$\begin{array}{l}\text { Sperm prepared by } \\
\text { swim up incubated } \\
\text { with } 600 \mu \mathrm{mol} \\
\text { vitamin } C \text { added } \\
\text { to media } \times 1 \text { hour }\end{array}$} & & 1. Reduced MDA levels & \multirow{4}{*}{$\begin{array}{l}\text { Fanaei et al. } \\
2014 \text { [60] }\end{array}$} \\
\hline & & & & & 2. Reduced DNA damage & \\
\hline & & & & & $\begin{array}{l}\text { 3. Improved sperm } \\
\text { progressive motility }\end{array}$ & \\
\hline & & & & & 4. Improved sperm viability & \\
\hline \multirow[t]{2}{*}{ Vitamin C } & \multirow[t]{2}{*}{ Prospective } & \multirow[t]{2}{*}{$\begin{array}{l}\text { DNA damaged } \\
\text { sperm from } \\
\text { infertile men }\end{array}$} & \multirow[t]{2}{*}{$\begin{array}{l}10 \text { mM ascorbic } \\
\text { acid added to } \\
\text { semen sample } \\
\text { prior to adding } \\
\text { cryomedia }\end{array}$} & $\begin{array}{l}\text { Unsupplemented } \\
\text { cryomedium }\end{array}$ & $\begin{array}{l}\text { 1. No change in } \\
\text { post-thaw sperm } \\
\text { concentration or } \\
\text { morphology }\end{array}$ & \multirow[t]{2}{*}{$\begin{array}{l}\text { Branco et al. } \\
\text { [61] }\end{array}$} \\
\hline & & & & & $\begin{array}{l}\text { 2. Reduced } \\
\text { number of sperm with } \\
\text { cryopreservation-induced } \\
\text { DNA damage in infertile men }\end{array}$ & \\
\hline Vitamin C & Prospective & $\begin{array}{l}\text { Sperm from patients } \\
\text { undergoing semen } \\
\text { analysis }(n=134)\end{array}$ & $\begin{array}{l}\text { Supplementation } \\
\text { of cryomedium } \\
\text { with ascorbate } \\
\text { or } 100 \mu \mathrm{mol} / \mathrm{L} \\
\text { AA2G (ascorbic } \\
\text { acid-2-glucoside) } \\
\text { (stabilized form } \\
\text { of ascorbate) }\end{array}$ & $\begin{array}{l}\text { Unsupplemented } \\
\text { cryomedium }\end{array}$ & $\begin{array}{l}\text { Improved post-thaw } \\
\text { sperm motility }\end{array}$ & $\begin{array}{l}\text { Jenkins et al. } \\
\text { [62] }\end{array}$ \\
\hline $\begin{array}{l}\text { Coenzyme } \\
Q_{10}\end{array}$ & Prospective & $\begin{array}{l}\text { Sperm from } \\
\text { asthenozoospermic } \\
\text { men }(n=22)\end{array}$ & $\begin{array}{l}\text { HAM's medium } \\
\text { alone, HAM's } \\
\text { medium }+1 \% \\
\text { DMSO, HAM's } \\
\text { medium }+5 \mu \mathrm{M} \\
\text { CoQ10 or } 50 \mu \mathrm{M} \\
\text { CoQ10 } \times 24 \text { hours }\end{array}$ & $\begin{array}{l}\text { Samples with } \\
\text { normal motility } \\
\text { sperm }(n=16)\end{array}$ & $\begin{array}{l}50 \mu \mathrm{M} \text { CoQ10 increased sperm } \\
\text { motility of asthenozoopsermic } \\
\text { men in vitro }\end{array}$ & $\begin{array}{l}\text { Lewin \& } \\
\text { Lavon [63] }\end{array}$ \\
\hline \multirow[t]{2}{*}{ Melatonin } & \multirow[t]{2}{*}{ Experimental } & \multirow{2}{*}{$\begin{array}{l}\text { Sperm from } \\
\text { both healthy } \\
\text { and infertile } \\
\text { men }(n=12)\end{array}$} & \multirow{2}{*}{$\begin{array}{l}\text { Sperm } \\
\text { co-incubated } \\
\text { with } 1 \mathrm{mM} \\
\text { melatonin } \mathrm{x} \\
30 \text { minutes }\end{array}$} & No treatment & $\begin{array}{l}\text { 1. Increased percentage } \\
\text { of motile and progressively } \\
\text { motile cells }\end{array}$ & \multirow[t]{2}{*}{$\begin{array}{l}\text { Ortiz et al. } \\
\text { [64] }\end{array}$} \\
\hline & & & & & $\begin{array}{l}\text { 2. Increased sperm } \\
\text { vitality and sperm } \\
\text { with normal } \\
\text { morphology }\end{array}$ & \\
\hline \multirow[t]{2}{*}{ Melatonin } & \multirow[t]{2}{*}{ Experimental } & \multirow[t]{2}{*}{$\begin{array}{l}\text { Sperm from } \\
\text { healthy men } \\
(n=12)\end{array}$} & \multirow[t]{2}{*}{$\begin{array}{l}\text { Sperm co-incubated } \\
\text { with } 2 \text { mM melatonin x } \\
120 \text { minutes }\end{array}$} & No treatment & $\begin{array}{l}\text { 1. Higher percentage } \\
\text { of motility and } \\
\text { progressive motility }\end{array}$ & \multirow[t]{2}{*}{$\begin{array}{l}\text { du Plessis et al. } \\
\text { [65] }\end{array}$} \\
\hline & & & & & $\begin{array}{l}\text { 2. Increased sperm } \\
\text { viability }\end{array}$ & \\
\hline
\end{tabular}




\section{Table 1 Study outcomes involving in vitro supplementation of various antioxidants during ART protocol (Continued)}

\begin{tabular}{|c|c|c|c|c|c|c|}
\hline L-Carnitine & Experimental & $\begin{array}{l}\text { Peritoneal fluid } \\
\text { from women } \\
\text { with endometriosis }\end{array}$ & $\begin{array}{l}\text { Frozen metaphase ॥ } \\
\text { mouse oocytes and } \\
\text { embryos in peritoneal } \\
\text { fluid (from endometriosis } \\
\text { patients) incubated with } \\
0.6 \mathrm{mg} / \mathrm{mL} \text { L-Carnitine }\end{array}$ & $\begin{array}{l}\text { Peritoneal fluid } \\
\text { (from endometriosis } \\
\text { patients) only, } \\
\text { peritoneal fluid } \\
\text { (from tubal ligation } \\
\text { patients as control) } \\
\text { only, human tubal } \\
\text { fluid only, } \\
\text { L-carnitine only }\end{array}$ & $\begin{array}{l}\text { 1. Improved } \\
\text { microtubule and } \\
\text { chromosome } \\
\text { structure in oocyte } \\
\text { 2. Decreased level of embryo } \\
\text { apoptosis }\end{array}$ & $\begin{array}{l}\text { Mansour et al. } \\
{[66]}\end{array}$ \\
\hline \multirow[t]{2}{*}{ L-Carnitine } & \multirow[t]{2}{*}{ Experimental } & \multirow[t]{2}{*}{ Embryo } & \multirow[t]{2}{*}{$\begin{array}{l}0.3 \mathrm{mg} / \mathrm{mL} \text { or } \\
0.6 \mathrm{mg} / \mathrm{mL} \\
\text { L-Carnitine }\end{array}$} & \multirow[t]{2}{*}{$\begin{array}{l}\text { Embryo culture } \\
\text { medium without } \\
\text { supplementation }\end{array}$} & $\begin{array}{l}\text { 1. Improved percentage } \\
\text { of blastocyst development } \\
\text { rate with } 0.3 \mathrm{mg} / \mathrm{mL} \\
\text { L-carnitine }\end{array}$ & \multirow[t]{2}{*}{$\begin{array}{l}\text { Abdelrazik et al } \\
{[67]}\end{array}$} \\
\hline & & & & & $\begin{array}{l}\text { 2. Both } 0.3 \mathrm{mg} / \mathrm{mL} \text { and } \\
0.6 \mathrm{mg} / \mathrm{mL} \text { L-carnitine } \\
\text { reduced the blocking effect } \\
\text { of actinomycin-D, hydrogen } \\
\text { peroxide or tumor necrosis } \\
\text { factor alpha and reduced } \\
\text { the level of DNA damage }\end{array}$ & \\
\hline
\end{tabular}

centrifugation-induced ROS production and damage to processed spermatozoa [82].

ART technique In the clinical setting, gamete and embryo manipulation in vitro during ART is a potential source of ROS production [4]. An IVF procedure involves long incubation time of spermatozoa, oocyte and its cumulus cells (which are potential ROS generators) in the fertilization medium. Conversely, ICSI has a shorter incubation period which involves only one spermatozoon and an oocyte that has been stripped of its cumulus cells. Hence, ICSI carries a lower risk of ROS production during fertilization compared to IVF [6]. However, ICSI carries a greater risk of exposing oocyte DNA to ROS-induced damage as there is a risk of transferring a small quantity of ROS-containing medium along with the spermatozoon into the oocyte [83]. Despite the selected spermatozoon having a morphologically-normal appearance, it may carry a greater risk of having DNA damage as natural spermatozoa selection are bypassed during the ICSI procedure and specifically more so as this is usually the technique of choice when spermatozoa quality is poor [84].

Cryopreservation (freeze/thawing) Cryopreservation involves the preservation of gametes/embryos and whole ovarian or testicular tissues by cooling to sub-zero temperatures followed by thawing for use in ART treatments [85]. Although the use of cryoprotectants and optimized protocols seem to enhance cell viability, the freeze-thaw process is an extreme stressor that can modify the structure and integrity of the cell, e.g. spermatozoa plasma membrane [86]. During cryopreservation, freeze-thaw procedures increase DNA oxidative damage and fragmentation levels, causing post-thaw spermatozoa to have poorer motility and viability $[87,88]$.

Antioxidant supplementation protect spermatozoa from the effects of the freeze-thaw process [89]. For example, supplementation of cryopreservation medium with quercetin [90] and catalase [91] seemed to protect spermatozoa from oxidative stress-induced damage during the freeze-thaw process and caused improvement in spermatozoa motility, viability and DNA integrity. Addition of Vitamin E [58] and pentoxifylline [92-95] respectively to cryopreservation medium/prior to cryopreservation improved post-thaw motility. Supplementation of spermatozoa preparation medium with biotin enhanced the motility of frozen-thawed spermatozoa and prolonged its survival [96]. Post-thaw spermatozoa quality is also influenced by the cryopreservation technique and type of cryoprotectant used [97]. Figure 2 depicts the effects of oxidative stress and possible interventions to overcome its detrimental effects at different ART steps.

However, the use of newer cryopreservation techniques such as vitrification has yielded vitrified oocytes that are as viable as fresh oocytes in terms of implantation rate, embryo survival rate and clinical pregnancy rate [98]. A controlled-randomized clinical trial confirmed that vitrification is an effective form of oocyte cryo-storage and is not inferior to the use of fresh oocytes [99]. This opens a favorable avenue for patients seeking fertility preservation or those at risk of ovarian hyperstimulation syndrome.

\section{Antioxidants as ameliorating agents}

In order to maintain physiological ROS levels and prevent oxidative stress development, excess ROS must be continuously neutralized. Antioxidants are able to neutralize 


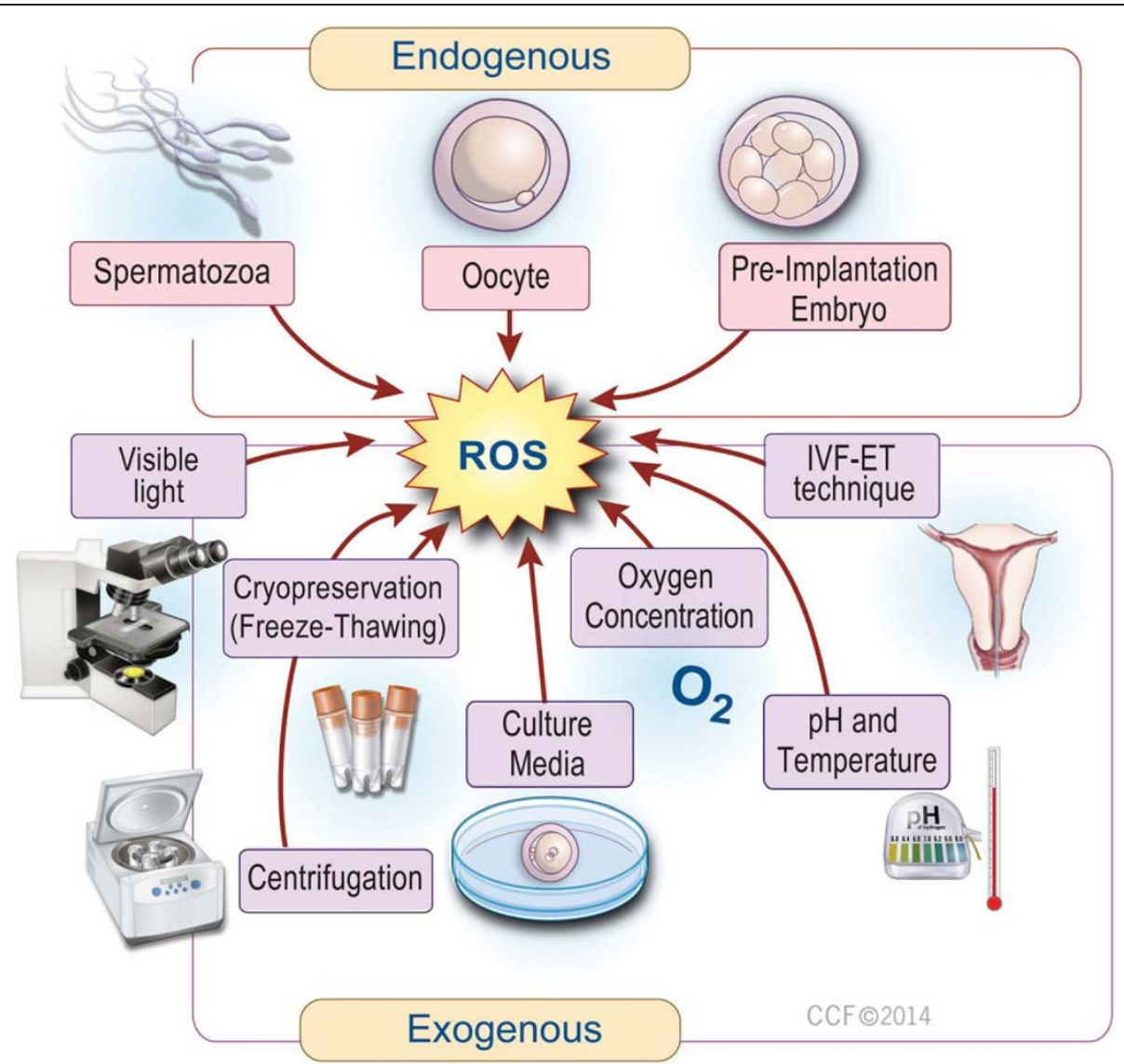

Figure 2 Effects of oxidative stress (OS) and interventions to overcome its effects at different ART steps. Overproduction of ROS could potentially occur at various steps during ART, leading to oxidative stress. Exposure of the developing embryo to oxidative stress may cause 2 cell block, reduction in blastomere numbers and blastocyst development rate, apoptosis and fragmentation of the embryo, leading to pre-implantation embryonic death. However, the appropriate intervention could be taken at various steps during ART to minimize the harmful effects of oxidative stress on ART outcome. These include: using a lower sperm concentration, shorter co-incubation periods, employment of appropriate sperm preparation techniques, the use of low levels of illumination and oxygen concentration, use of appropriate type and content of media, including supplementation with antioxidants.

pro-oxidants by either preventing its formation via termination of propagative oxidative chain reactions or by scavenging existing ROS, thereby maintaining the delicate pro-oxidant/anti-oxidant balance and consequently protecting the cell and its microenvironment from oxidative damage [4,100]. Examples of antioxidant systems include enzymes such as SOD, catalase and glutathione peroxidase/reductase, and a variety of non-enzymes such as vitamins (E, C, B complex), polyphenols (flavonoids), carotenoids and trace minerals among others [15]. Components of the human reproductive system contain antioxidants that are either endogenously formed or acquired from dietary sources [13]. In females, antioxidants are present in the ovary, follicles, follicular, tubal and peritoneal fluid, and endometrial epithelium [6], while in males, antioxidants are found in the testis, epididymis, secretions of the male accessory organs and seminal plasma [17].
In an ART setting, antioxidants can be employed to ameliorate the harmful effects of excess ROS on gametes and embryos. Treatment strategies using antioxidants may be approached in two general modes, either as oral supplementation of the subfertile couple several months prior to their ART cycle, or as in vitro supplementation in media during the ART protocol itself, in order to minimize endogenous and exogenous sources of ROS, respectively. The role of antioxidants in assisted reproduction is indeed one of great importance. For example, in infertile men undergoing IVF and ICSI, high seminal ROS levels correlate negatively with spermatozoa morphology and vitality, and fertilization rates, while seminal antioxidant levels showed a positive correlation with fertilization rates. Although ROS levels were higher in IVF than in ICSI patient groups, total antioxidant concentration in seminal plasma and fertilization 
rates did not differ between the IVF and ICSI cohorts [9]. Seminal antioxidants, in general enhance spermatozoa quality leading to higher ART success rates. Tables 2 and 3 contain a summary of key findings of studies using oral supplementation of antioxidants respectively in men and in women.

\section{Enzymatic antioxidants}

In normozoospermic men, higher seminal activities of enzymatic antioxidants correlate with lower total malondialdehyde levels (MDA), indicating the protective effect of these antioxidants against oxidative stress-induced lipid peroxidation [133,134]. Conversely, infertile men with poor spermatozoa quality have lower levels of seminal enzymatic antioxidants that correspond with increased levels of lipid peroxidation $[133,135]$.

\section{Superoxide dismutase}

Isoforms of SOD found in mitochondria (manganese SOD) and cytoplasm (copper/zinc SOD) provide fundamental defense against ROS [136]. Normozoospermic men have higher seminal SOD activity compared to men with abnormal sperm parameters. Seminal SOD activity correlates positively with spermatozoa concentration and motility and inversely with both sperm DNA fragmentation and semen volume $[137,138]$. SOD activity is present in granulosa and theca interna cells of preantral, antral and in dominant follicles, with increasing expression towards ovulation [139]. Women with tubal factor infertility who failed to conceive had lower SOD activity in their granulosa cells and a reduction in embryo quality [140]. Furthermore it was shown that higher SOD activity in cumulus cells from women with infertile partners lead to better ART outcome. Thus, SOD activity may be indicative of a better quality oocyte during oocyte selection [31].

\section{Catalase}

Found in cellular peroxisomes, catalase decomposes hydrogen peroxide to oxygen and water [141]. Catalase, originating mainly from the prostate gland, is present in seminal fluid and motile spermatozoa [142]. Low seminal catalase activity poses a greater risk of post-fertilization failure in infertile couples undergoing IVF [143]. Catalase added to spermatozoa preparation media resulted in reduced ROS and DNA fragmentation levels and an increased acrosome reaction rate in spermatozoa from normozoospermic men [144]. During spermatozoa cryopreservation, supplementation of cryomedia with catalase gave better freeze-thaw outcomes, with higher spermatozoa motility, vitality and lesser DNA damage [91,145]. Similarly, co-supplementation of cryopreserved spermatozoa with catalase and SOD gave higher post-thaw motility and viability [146].

\section{Glutathione system}

The glutathione enzymatic family comprises reduced glutathione $(\mathrm{GSH})$, glutathione peroxidase ( $\mathrm{GPx}$, isoforms Gpx 1 to GPx 6), glutathione-S transferase (GST) and glutathione reductase (GR). GSH is a non-enzymatic antioxidant peptide formed in the cytosol from glycine, cysteine, and glutamate. GSH is oxidized to gluthathione disulphide (GSSG) by GPx. There are 6 isoforms of GPx: the selenocysteine-containing GPx1 to GPx4, and seleniumindependent GPx5, which is present in the epididymis. All GPx isozymes reduce hydrogen peroxide and lipid hydroxyperoxides $[147,148]$. Seminal GPx activity is lower in infertile men with abnormal spermatozoa quality, but no correlation was found between GPx levels and spermatozoa fertilization potential or pregnancy rates in IVF [149].

\section{Non-enzymatic antioxidants}

\section{Vitamins and vitamin-like substances}

Vitamin E Vitamin E is a naturally-occurring, lipidsoluble antioxidant. It's most active form, alpha-tocopherol quenches hydrogen peroxide, superoxide anion, hydroxyl anions and breaks peroxidation chain reactions. RCTs and prospective studies concur that oral supplementation of vitamin E reduces lipid peroxidation damage [102,150], improves sperm motility [102,103] and function [101] as well as improve fertilization [150] and pregnancy rates $[102,103]$. In a small prospective study $(n=15)$, Geva's group showed that oral vitamin E (200 mg for 3 months) increased oocyte fertilization rate per IVF cycle in fertile, normozoospermic men who initially had low fertilization rates during a previous IVF attempt. Following antioxidant therapy with vitamin $\mathrm{E}$, these men also experienced lower lipid peroxidation levels in their spermatozoa [150]. In women with unexplained infertility, oral vitamin $\mathrm{E}$ intake improved the endometrial response, possibly due to its antioxidant and anticoagulant effects as well as by modulating the anti-estrogenic effect of clomiphene citrate. However, no differences in implantation or pregnancy rates were observed [122]. The in vitro effects of vitamin $\mathrm{E}$ on normal and abnormal spermatozoa during cryopreservation are improved post-thaw motility [57,58] and DNA integrity [57], while addition during incubation improved motility and viability of abnormal spermatozoa [59].

Selenium, an essential micronutrient and a free radical-scavenger, works synergistically with Vitamin E to protect spermatozoa from the effects of oxidation [104] and to improve motility [104,105], morphology and pregnancy rates [105]. Found in high concentrations in testicular tissue, selenium is required for testosterone synthesis and spermatogenesis [151,152]. Moslemi and Tavanbakhsh studied the effects of vitamin $\mathrm{E}$ and selenium 
Table 2 Study outcomes involving oral supplementation of various antioxidants in men

\begin{tabular}{|c|c|c|c|c|c|c|}
\hline Antioxidant & Study type & Patient population & $\begin{array}{l}\text { Intervention (daily } \\
\text { dose } \mathrm{x} \text { duration) }\end{array}$ & $\begin{array}{l}\text { Control group } \\
\text { (daily dose) }\end{array}$ & $\begin{array}{l}\text { Study outcome (effect } \\
\text { on sperm parameters) }\end{array}$ & Reference \\
\hline Vitamin E & $\begin{array}{l}\text { Double blind, } \\
\text { placebo cross- } \\
\text { over, RCT }\end{array}$ & $\begin{array}{l}\text { Healthy men with } \\
\text { high seminal ROS } \\
\text { levels }(n=30)\end{array}$ & $\begin{array}{l}600 \text { mg vitamin } E x \\
3 \text { months }(n=15)\end{array}$ & $\begin{array}{l}\text { Placebo } \\
(n=15)\end{array}$ & $\begin{array}{l}\text { Improved in vitro sperm } \\
\text { function (improved zona- } \\
\text { binding assay) }\end{array}$ & $\begin{array}{l}\text { Kessopoulou } \\
\text { et al. [101] }\end{array}$ \\
\hline \multirow[t]{3}{*}{ Vitamin $E$} & \multirow{3}{*}{$\begin{array}{l}\text { Double blind, } \\
\text { placebo- } \\
\text { controlled }\end{array}$} & \multirow{3}{*}{$\begin{array}{l}\text { Men with }(n=110) \\
\text { asthenozoospermia or } \\
\text { oligoasthenozoospermia }\end{array}$} & \multirow[t]{3}{*}{$\begin{array}{l}300 \text { mg vitamin } E x \\
6 \text { months }(n=52)\end{array}$} & \multirow[t]{3}{*}{$\begin{array}{l}\text { Placebo } \\
(n=55)\end{array}$} & $\begin{array}{l}\text { 1. Reduced MDA concentration } \\
\text { (less LPO in spermatozoa) }\end{array}$ & \multirow[t]{3}{*}{$\begin{array}{l}\text { Suleiman } \\
\text { et al. [102] }\end{array}$} \\
\hline & & & & & 2. Improved sperm motility & \\
\hline & & & & & $\begin{array}{l}\text { 3. } 20 \% \text { of those on therapy } \\
\text { achieved pregnancy }\end{array}$ & \\
\hline \multirow{2}{*}{$\begin{array}{l}\text { Vitamin } E+ \\
\text { Anti-Estrogen } \\
\text { (Clomiphene } \\
\text { citrate) }\end{array}$} & \multirow{2}{*}{$\begin{array}{l}\text { Prospective, } \\
\text { placebo- } \\
\text { controlled RCT }\end{array}$} & \multirow{2}{*}{$\begin{array}{l}\text { Infertile men } \\
\text { with idiopathic } \\
\text { oligozoospermia } \\
(\mathrm{n}=60)\end{array}$} & \multirow{2}{*}{$\begin{array}{l}400 \mathrm{mg} \text { vitamin } \mathrm{E} \\
+25 \mathrm{mg} \text { clomiphene } \\
\text { citrate } \times 6 \text { months } \\
(\mathrm{n}=30)\end{array}$} & \multirow[t]{2}{*}{$\begin{array}{l}\text { Placebo } \\
(n=30)\end{array}$} & $\begin{array}{l}\text { 1. Improved sperm count and } \\
\text { progressive motility }\end{array}$ & \multirow{2}{*}{$\begin{array}{l}\text { Ghanem } \\
\text { et al. [103] }\end{array}$} \\
\hline & & & & & $\begin{array}{l}\text { 2. Partners had higher incidence } \\
\text { of pregnancy }\end{array}$ & \\
\hline \multirow[t]{2}{*}{$\begin{array}{l}\text { Vitamin } E+ \\
\text { selenium }\end{array}$} & \multirow[t]{2}{*}{$\begin{array}{l}\text { Open, } \\
\text { randomized }\end{array}$} & \multirow{2}{*}{$\begin{array}{l}\text { Volunteers and } \\
\text { infertile men } \\
(n=54)\end{array}$} & \multirow{2}{*}{$\begin{array}{l}400 \mathrm{mg} \text { vitamin } \mathrm{E} \\
+225 \mu \mathrm{g} \text { selenium } x \\
3 \text { months }(\mathrm{n}=28)\end{array}$} & \multirow{2}{*}{$\begin{array}{l}4.5 \mathrm{~g} \\
\text { vitamin } \mathrm{B} x \\
3 \text { months } \\
(\mathrm{n}=26)\end{array}$} & $\begin{array}{l}\text { 1. Reduced MDA concentration } \\
\text { (less LPO in spermatozoa) }\end{array}$ & \multirow[t]{2}{*}{$\begin{array}{l}\text { Keskes-Amma } \\
\text { et al. [104] }\end{array}$} \\
\hline & & & & & 2. Improved sperm motility & \\
\hline \multirow[t]{2}{*}{$\begin{array}{l}\text { Vitamin } E+ \\
\text { selenium }\end{array}$} & \multirow[t]{2}{*}{$\begin{array}{l}\text { Observational } \\
\text { study }\end{array}$} & \multirow{2}{*}{$\begin{array}{l}\text { Infertile men } \\
\text { with idiopathic } \\
\text { asthenozoospermia } \\
(n=690)\end{array}$} & \multirow[t]{2}{*}{$\begin{array}{l}400 \mathrm{IU} \text { vitamin } E \\
+200 \mu \mathrm{g} \text { selenium } x \\
100 \text { days }\end{array}$} & \multirow[t]{2}{*}{ None } & $\begin{array}{l}\text { 1. Improvement in sperm } \\
\text { motility/morphology or both } \\
(53 \%)\end{array}$ & \multirow[t]{2}{*}{$\begin{array}{l}\text { Moslemi \& } \\
\text { Tavanbakhsh } \\
\text { [105] }\end{array}$} \\
\hline & & & & & $\begin{array}{l}\text { 2. Increased spontaneous } \\
\text { pregnancy rates }(11 \%)\end{array}$ & \\
\hline \multirow[t]{2}{*}{$\begin{array}{l}\text { Vitamin } E+ \\
\text { Vitamin } C\end{array}$} & \multirow{2}{*}{$\begin{array}{l}\text { Double blind, } \\
\text { placebo- } \\
\text { controlled, RCT }\end{array}$} & \multirow{2}{*}{$\begin{array}{l}\text { Men }(n=31) \text { with } \\
\text { asthenozoospermia } \\
\text { or moderate } \\
\text { oligoasthenozoospermia }\end{array}$} & \multirow{2}{*}{$\begin{array}{l}1000 \mathrm{mg} \text { vitamin } C \\
+800 \mathrm{mg} \text { vitamin } \mathrm{Ex} \\
8 \text { weeks }(\mathrm{n}=15)\end{array}$} & \multirow[t]{2}{*}{$\begin{array}{l}\text { Placebo } \\
(n=16)\end{array}$} & $\begin{array}{l}\text { No improvement in sperm } \\
\text { parameters }\end{array}$ & \multirow[t]{2}{*}{$\begin{array}{l}\text { Rolf et al. } \\
\text { [106] }\end{array}$} \\
\hline & & & & & $\begin{array}{l}\text { No improvement in } 24 \mathrm{~h} \text { sperm } \\
\text { survival rate }\end{array}$ & \\
\hline $\begin{array}{l}\text { Vitamin } E+ \\
\text { Vitamin } C\end{array}$ & $\begin{array}{l}\text { Observational } \\
\text { study, double- } \\
\text { blind }\end{array}$ & $\begin{array}{l}\text { Men with elevated } \\
\text { sperm DNA } \\
\text { fragmentation } \\
(\geq 15 \%) \text { who have } \\
\text { unexplained infertility }\end{array}$ & $\begin{array}{l}1000 \mathrm{mg} \text { vitamin } C \\
+1000 \mathrm{mg} \text { vitamin } E x \\
2 \text { months }(\mathrm{n}=32)\end{array}$ & $\begin{array}{l}\text { Placebo } \\
(n=32)\end{array}$ & $\begin{array}{l}\text { Reduced percentage of } \\
\text { DNA-fragmented sperm } \\
\text { (TUNEL test) }\end{array}$ & $\begin{array}{l}\text { Greco et al. } \\
{[107]}\end{array}$ \\
\hline \multirow[t]{2}{*}{$\begin{array}{l}\text { Vitamin } E+ \\
\text { Vitamin } C\end{array}$} & \multirow{6}{*}{$\begin{array}{l}\text { Observational } \\
\text { study } \\
\text { involving } \\
\text { assisted } \\
\text { conception } \\
\text { treatment }\end{array}$} & \multirow{2}{*}{$\begin{array}{l}\text { Men with elevated } \\
\text { sperm DNA } \\
\text { fragmentation } \\
(\geq 15 \%) \text { who failed } \\
\text { their } 1^{\text {st }} \text { ICSI attempt }\end{array}$} & \multirow[t]{2}{*}{$\begin{array}{l}1000 \mathrm{mg} \text { vitamin } C \\
+1000 \mathrm{mg} \text { vitamin } E x \\
2 \text { months }(n=38)\end{array}$} & \multirow[t]{2}{*}{ None } & $\begin{array}{l}\text { 1. Reduced percentage of } \\
\text { DNA-fragmented sperm } \\
\text { (TUNEL test) }\end{array}$ & $\begin{array}{l}\text { Greco et al. } \\
{[108]}\end{array}$ \\
\hline & & & & & $\begin{array}{l}\text { 2. Marked improvement in } \\
\text { implantation and clinical } \\
\text { pregnancy rates in the } 2^{\text {nd }} \text { ICSI } \\
\text { attempt vs } 1^{\text {st }} \text { attempt }\end{array}$ & \\
\hline Vitamin C & & $\begin{array}{l}\text { Men with sperm } \\
\text { agglutination } \\
(>25 \%)(n=30)\end{array}$ & $\begin{array}{l}200 \mathrm{mg} \text { vitamin C or } \\
1000 \mathrm{mg} \text { vitamin C }\end{array}$ & Placebo & $\begin{array}{l}\text { Improved sperm motility, } \\
\text { viability, morphology after } \\
4 \text { weeks (more prominent } \\
\text { improvement in } 1000 \mathrm{mg} \\
\text { vitamin C vs. } 200 \mathrm{mg} \text { vitamin C) }\end{array}$ & $\begin{array}{l}\text { Dawson et al. } \\
{[109]}\end{array}$ \\
\hline Vitamin C & & $\begin{array}{l}\text { Men who are heavy } \\
\text { smokers }(n=75) \text { with }\end{array}$ & $\begin{array}{l}200 \mathrm{mg} \text { vitamin } C \text { or } \\
1000 \mathrm{mg} \text { vitamin } \mathrm{C}\end{array}$ & Placebo & $\begin{array}{l}\text { 1. Improved sperm } \\
\text { agglutination }\end{array}$ & $\begin{array}{l}\text { Dawson et al. } \\
{[110]}\end{array}$ \\
\hline & & $\begin{array}{l}\text { normal reproductive } \\
\text { function }\end{array}$ & & & 2. Improved 24 h viability & \\
\hline & & & & & 3. Improved sperm morphology & \\
\hline $\begin{array}{l}\text { Folic acid + } \\
\text { zinc sulphate }\end{array}$ & $\begin{array}{l}\text { Double blind, } \\
\text { placebo- } \\
\text { controlled, RCT }\end{array}$ & $\begin{array}{l}\text { Fertile }(n=108) \text { and } \\
\text { subfertile men }(n=103)\end{array}$ & $\begin{array}{l}5 \mathrm{mg} \text { folic acid, } 66 \mathrm{mg} \\
\text { zinc sulphate or } 5 \mathrm{mg} \\
\text { folic acid }+66 \mathrm{mg} \text { zinc } \\
\text { sulphate } \times 26 \text { weeks }\end{array}$ & $\begin{array}{l}\text { Placebo or } \\
\text { placebo }+ \\
\text { placebo }\end{array}$ & $\begin{array}{l}\text { Increased sperm concentration } \\
\text { in subfertile and fertile males } \\
\text { after combined treatment }\end{array}$ & $\begin{array}{l}\text { Wong et al. } \\
{[111]}\end{array}$ \\
\hline $\begin{array}{l}\text { Folic acid + } \\
\text { zinc sulphate }\end{array}$ & $\begin{array}{l}\text { Double blind, } \\
\text { placebo- } \\
\text { controlled }\end{array}$ & $\begin{array}{l}\text { Fertile }(n=47) \text { and } \\
\text { subfertile men }(n=40)\end{array}$ & $\begin{array}{l}5 \mathrm{mg} \text { folic acid }+66 \mathrm{mg} \\
\text { zinc sulphate } \times 26 \text { weeks }\end{array}$ & Placebo & $\begin{array}{l}\text { Increased sperm concentration } \\
\text { in infertile males, but not fertile } \\
\text { males }\end{array}$ & $\begin{array}{l}\text { Ebisch et al. } \\
\text { [112] }\end{array}$ \\
\hline
\end{tabular}


Table 2 Study outcomes involving oral supplementation of various antioxidants in men (Continued)

\begin{tabular}{|c|c|c|c|c|c|c|}
\hline $\begin{array}{l}\text { Folic acid + } \\
\text { zinc sulphate }\end{array}$ & $\begin{array}{l}\text { Double blind, } \\
\text { placebo } \\
\text { controlled, RCT }\end{array}$ & $\begin{array}{l}\text { Subfertile men with } \\
\text { OAT }(n=83)\end{array}$ & $\begin{array}{l}5 \mathrm{mg} \text { folic acid }+220 \mathrm{mg} \\
\text { zinc sulphate } \times 16 \text { weeks }\end{array}$ & Placebo & $\begin{array}{l}\text { Zinc sulfate }+ \text { folic acid did } \\
\text { not improve sperm quality } \\
\text { in men with OAT (severely } \\
\text { compromised sperm } \\
\text { parameters) }\end{array}$ & $\begin{array}{l}\text { Raigani et al. } \\
\text { [113] }\end{array}$ \\
\hline \multirow[t]{2}{*}{$\begin{array}{l}\text { Folic acid }+ \\
\text { zinc sulphate }\end{array}$} & \multirow[t]{2}{*}{$\begin{array}{l}\text { Prospective, } \\
\text { randomized } \\
\text { controlled }\end{array}$} & \multirow[t]{2}{*}{$\begin{array}{l}\text { Men with palpable } \\
\text { varicocele (grade III) } \\
\text { who underwent } \\
\text { surgical repair of } \\
\text { varicocele }(n=160)\end{array}$} & \multirow{2}{*}{$\begin{array}{l}5 \mathrm{mg} \text { folic acid }(n=26), \\
66 \mathrm{mg} \text { zinc sulphate } \\
(\mathrm{n}=32) \text { or } 5 \mathrm{mg} \\
\text { folic acid }+66 \mathrm{mg} \\
\text { zinc sulphate }(\mathrm{n}=29) \\
\times 6 \text { months }\end{array}$} & \multirow[t]{2}{*}{$\begin{array}{l}\text { Placebo } \\
(n=25)\end{array}$} & $\begin{array}{l}\text { 1. Zinc sulfate }+ \text { folic acid } \\
\text { improved sperm parameters } \\
\text { and improved varicocelectomy } \\
\text { outcomes }\end{array}$ & \multirow[t]{2}{*}{$\begin{array}{l}\text { Azizollahi } \\
\text { et al. [114] }\end{array}$} \\
\hline & & & & & $\begin{array}{l}\text { 2. Improved protamine } \\
\text { content and halo formation } \\
\text { rate }\end{array}$ & \\
\hline \multirow[t]{5}{*}{$\begin{array}{l}\text { Coenzyme } \\
Q_{10}\end{array}$} & \multirow{5}{*}{$\begin{array}{l}\text { Systematic } \\
\text { review and } \\
\text { meta-analysis } \\
\text { (3 RCTs) }\end{array}$} & \multirow[t]{5}{*}{ Infertile men } & \multirow[t]{5}{*}{$\mathrm{CoQ}_{10}(\mathrm{n}=149)$} & \multirow[t]{5}{*}{$\begin{array}{l}\text { Controls } \\
(n=147)\end{array}$} & $\begin{array}{l}\text { 1. Improved seminal } \\
\mathrm{CoQ}_{10} \text { levels }\end{array}$ & \multirow[t]{5}{*}{$\begin{array}{l}\text { Lafuente } \\
\text { et al. [115] }\end{array}$} \\
\hline & & & & & $\begin{array}{l}\text { 2. Increased sperm } \\
\text { concentration }\end{array}$ & \\
\hline & & & & & 3. Increased sperm motility & \\
\hline & & & & & $\begin{array}{l}\text { 4. No increase in pregnancy } \\
\text { rates }\end{array}$ & \\
\hline & & & & & $\begin{array}{l}\text { 5. Data on live births were } \\
\text { lacking }\end{array}$ & \\
\hline \multirow[t]{4}{*}{$\begin{array}{l}\text { Coenzyme } \\
Q_{10}\end{array}$} & \multirow[t]{4}{*}{$\begin{array}{l}\text { Double } \\
\text { blind, placebo- } \\
\text { controlled, RCT }\end{array}$} & \multirow[t]{4}{*}{$\begin{array}{l}\text { Men with iOT } \\
(n=60)\end{array}$} & \multirow[t]{4}{*}{$\begin{array}{l}200 \mathrm{mg} \mathrm{CoQ} \mathrm{C}_{10} \times \\
3 \text { months }(\mathrm{n}=30)\end{array}$} & \multirow[t]{4}{*}{$\begin{array}{l}\text { Placebo } \\
\text { (Lactose) } \\
(n=30)\end{array}$} & $\begin{array}{l}\text { 1. Increased levels of } \\
\mathrm{CoQ}_{10} \text { in seminal } \\
\text { plasma }\end{array}$ & \multirow[t]{4}{*}{$\begin{array}{l}\text { Nadjarzadeh } \\
\text { et al. [116] }\end{array}$} \\
\hline & & & & & $\begin{array}{l}\text { 2. Decreased 8-isoprostane } \\
\text { levels (biomarker of LPO) } \\
\text { (attenuation of OS in seminal } \\
\text { plasma) }\end{array}$ & \\
\hline & & & & & $\begin{array}{l}\text { 3. Increased sperm forward and } \\
\text { total motility }\end{array}$ & \\
\hline & & & & & $\begin{array}{l}\text { 4. Increased catalase, SOD } \\
\text { activity }\end{array}$ & \\
\hline \multirow[t]{2}{*}{$\begin{array}{l}\text { Coenzyme } \\
Q_{10}\end{array}$} & \multirow{2}{*}{$\begin{array}{l}\text { Double } \\
\text { blind, placebo- } \\
\text { controlled, RCT }\end{array}$} & \multirow[t]{2}{*}{$\begin{array}{l}\text { Men with iOAT } \\
(n=47)\end{array}$} & \multirow[t]{2}{*}{$\begin{array}{l}200 \mathrm{mg} \mathrm{CoQ} 10 \times \\
12 \text { weeks }\end{array}$} & \multirow[t]{2}{*}{ Placebo } & $\begin{array}{l}\text { 1. Reduced TBARS (reduced } \\
\text { plasma MDA levels) }\end{array}$ & \multirow[t]{2}{*}{$\begin{array}{l}\text { Nadjarzadeh } \\
\text { et al. [117] }\end{array}$} \\
\hline & & & & & $\begin{array}{l}\text { 2. Increased TAC in seminal } \\
\text { plasma }\end{array}$ & \\
\hline $\begin{array}{l}\text { Coenzyme } \\
Q_{10}\end{array}$ & $\begin{array}{l}\text { Double } \\
\text { blind, placebo- } \\
\text { controlled, RCT }\end{array}$ & $\begin{array}{l}\text { Men with iOAT } \\
(n=228)\end{array}$ & $\begin{array}{l}200 \text { mg ubiquinol } x \\
26 \text { weeks }(n=114)\end{array}$ & $\begin{array}{l}\text { Placebo } \\
(n=114)\end{array}$ & $\begin{array}{l}\text { Improved sperm quality } \\
\text { (density, motility, normal } \\
\text { strict morphology) }\end{array}$ & $\begin{array}{l}\text { Safarinejad } \\
\text { et al. [118] }\end{array}$ \\
\hline \multirow[t]{2}{*}{$\begin{array}{l}\text { Coenzyme } \\
Q_{10}\end{array}$} & \multirow[t]{2}{*}{$\begin{array}{l}\text { Double } \\
\text { blind, placebo- } \\
\text { controlled, RCT }\end{array}$} & \multirow[t]{2}{*}{$\begin{array}{l}\text { Men with idiopathic } \\
\text { infertility }(n=60)\end{array}$} & \multirow[t]{2}{*}{$\begin{array}{l}200 \mathrm{mg} \mathrm{CoQ} 10 \times \\
6 \text { months }\end{array}$} & \multirow[t]{2}{*}{ Placebo } & $\begin{array}{l}\text { 1. Increase in } \mathrm{CoQ}_{10} \\
\text { and ubiquinol in seminal } \\
\text { plasma and spermatozoa }\end{array}$ & \multirow[t]{2}{*}{$\begin{array}{l}\text { Balercia } \\
\text { et al. [119] }\end{array}$} \\
\hline & & & & & $\begin{array}{l}\text { 2. Increase in spermatozoa } \\
\text { motility }\end{array}$ & \\
\hline \multirow[t]{2}{*}{$\begin{array}{l}\text { Coenzyme } \\
Q_{10}\end{array}$} & \multirow[t]{2}{*}{ Prospective } & \multirow[t]{2}{*}{$\begin{array}{l}\text { Men with iOAT } \\
(\mathrm{n}=212)\end{array}$} & \multirow[t]{2}{*}{$\begin{array}{l}300 \mathrm{mg} \mathrm{CoQ} \mathrm{Co}_{10} \times \\
26 \text { weeks }(\mathrm{n}=106)\end{array}$} & \multirow[t]{2}{*}{$\begin{array}{l}\text { Placebo } \\
(n=106)\end{array}$} & $\begin{array}{l}\text { 1. Improved sperm density, } \\
\text { motility, normal strict } \\
\text { morphology }\end{array}$ & $\begin{array}{l}\text { Safarinejad } \\
{[120]}\end{array}$ \\
\hline & & & & & 2. Improved acrosome reaction & \\
\hline $\begin{array}{l}\text { Coenzyme } \\
Q_{10}\end{array}$ & $\begin{array}{l}\text { Open-label, } \\
\text { prospective }\end{array}$ & $\begin{array}{l}\text { Men with iOAT } \\
(n=287)\end{array}$ & $\begin{array}{l}600 \text { mg CoQ } \\
12 \text { months }(n=106)\end{array}$ & None & $\begin{array}{l}\text { 1. Improved sperm quality } \\
\text { (concentration, progressive } \\
\text { motility, normal morphology) }\end{array}$ & $\begin{array}{l}\text { Safarinejad } \\
{[121]}\end{array}$ \\
\hline & & & & & 2. Improved pregnancy rates & \\
\hline
\end{tabular}

therapy for 14 weeks in 690 asthenoteratozoospermic infertile men from couples with male factor infertility. Semen analysis was found to be improved in 362 or $52.6 \%$ patients: 299 patients showed improved motility, 21 patients showed improved morphology and 42 patients showed improvement in both sperm motility and morphology. However, 253 cases (36.6\%) showed no change in their semen analysis, while the remaining 75 patients (10.8\%) 
Table 3 Study outcomes involving oral supplementation of various antioxidants in women

\begin{tabular}{|c|c|c|c|c|c|c|}
\hline Antioxidant & Study type & $\begin{array}{l}\text { Patient } \\
\text { population }\end{array}$ & $\begin{array}{l}\text { Intervention (daily } \\
\text { dose } \mathrm{x} \text { duration) }\end{array}$ & $\begin{array}{l}\text { Control group } \\
\text { (daily dose) }\end{array}$ & Study outcome & Reference \\
\hline \multirow[t]{2}{*}{ Vitamin E } & & \multirow[b]{2}{*}{$\begin{array}{l}\text { Women with } \\
\text { unexplained } \\
\text { infertility } \\
\text { undergoing } \\
\text { ovarian } \\
\text { stimulation } \\
\text { and then IUI }\end{array}$} & \multirow[t]{2}{*}{$400 \mathrm{IU} /$ day vitamin $\mathrm{E}$} & & 1. Increased endometrial thickness & \multirow{2}{*}{$\begin{array}{l}\text { Cicek et al. } \\
\text { [122] }\end{array}$} \\
\hline & & & & & $\begin{array}{l}\text { 2. No significant increase in } \\
\text { implantation and pregnancy rates }\end{array}$ & \\
\hline Vitamin C & Prospective & $\begin{array}{l}\text { Women } \\
\text { undergoing } \\
\text { IVF-ET }(n=76)\end{array}$ & $\begin{array}{l}500 \text { mg vitamin C/day } \\
\text { (slow release) to women } \\
\text { smokers }(n=19) \text { and } \\
\text { women non-smokers } \\
(n=19)\end{array}$ & Placebo & $\begin{array}{l}\text { Women non-smokers had higher } \\
\text { pregnancy rates than women smokers }\end{array}$ & $\begin{array}{l}\text { Crha et al. } \\
\text { [123] }\end{array}$ \\
\hline \multirow[t]{2}{*}{ Vitamin C } & \multirow{2}{*}{$\begin{array}{l}\text { Prospective, } \\
\text { randomized }\end{array}$} & \multirow{2}{*}{$\begin{array}{l}\text { Infertile women } \\
\text { with luteal } \\
\text { phase defects } \\
\text { (not on IVF-ET) }\end{array}$} & \multirow{2}{*}{$\begin{array}{l}750 \mathrm{mg} \text { ascorbic acid } \\
(\mathrm{n}=76) \text { started on first } \\
\text { day of third menstrual } \\
\text { cycle until positive urine } \\
\text { pregnancy test } \\
\text { (maximum } 6 \text { months) }\end{array}$} & \multirow{2}{*}{$\begin{array}{l}\text { No treatment } \\
(\mathrm{n}=46)\end{array}$} & 1. Increase in progesterone levels & \multirow{2}{*}{$\begin{array}{l}\text { Henmi } \\
\text { et al. [124] }\end{array}$} \\
\hline & & & & & 2. Increase in clinical pregnancy rates & \\
\hline Vitamin C & $\begin{array}{l}\text { Double blind, } \\
\text { placebo- } \\
\text { controlled, RCT }\end{array}$ & $\begin{array}{l}\text { Women }(<40 y) \\
\text { undergoing first } \\
\text { IVF-ET cycles } \\
(n=620)\end{array}$ & $\begin{array}{l}1 \mathrm{~g} \text { or } 5 \mathrm{~g} \text { or } 10 \mathrm{~g} \\
\text { ascorbic acid }+30 \mathrm{mg} \\
\text { Dydrogesteron } \times 14 \text { days } \\
\text { after follicle aspiration for } \\
\text { IVF-ET }\end{array}$ & $\begin{array}{l}\text { Placebo } \\
\text { (Lactose + citric } \\
\text { acid +30 mg } \\
\text { Dydrogesteron) }\end{array}$ & $\begin{array}{l}\text { No difference in clinical pregnancy } \\
\text { and implantation rates }\end{array}$ & $\begin{array}{l}\text { Griesinger } \\
\text { et al. [125] }\end{array}$ \\
\hline $\begin{array}{l}\text { Myo-inositol + } \\
\text { folic acid }\end{array}$ & $\begin{array}{l}\text { Placebo- } \\
\text { controlled, RCT }\end{array}$ & $\begin{array}{l}\text { Infertile PCOS } \\
\text { patients } \\
\text { undergoing } \\
\text { ovulation } \\
\text { induction for } \\
\text { ICSI }(n=60)\end{array}$ & $\begin{array}{l}4 \mathrm{~g} \text { myo-inositol }+400 \mu \mathrm{g} \\
\text { folic acid }(n=30)\end{array}$ & $\begin{array}{l}400 \mu g \text { folic } \\
\text { acid only } \\
(n=30)\end{array}$ & $\begin{array}{l}\text { Reduced germinal vesicles and } \\
\text { degenerated oocytes without } \\
\text { compromising the number of } \\
\text { oocytes retrieved at ovum pick-up }\end{array}$ & $\begin{array}{l}\text { Papaleo } \\
\text { et al. [126] }\end{array}$ \\
\hline \multirow[t]{3}{*}{$\begin{array}{l}\text { Myo-inositol + } \\
\text { folic acid }\end{array}$} & \multirow[t]{3}{*}{ Double blind } & \multirow{3}{*}{$\begin{array}{l}\text { Infertile PCOS } \\
\text { patients } \\
\text { undergoing } \\
\text { ovulation } \\
\text { induction for } \\
\text { IVF or ICSI } \\
(\mathrm{n}=34)\end{array}$} & \multirow{3}{*}{$\begin{array}{l}4 \mathrm{~g} \text { of myo-inositol } \\
+400 \mu \mathrm{g} \text { of folic acid, } \\
\text { continuously for } \\
3 \text { months }\end{array}$} & \multirow[t]{3}{*}{$\begin{array}{l}400 \mu \mathrm{g} \text { of folic } \\
\text { acid only }\end{array}$} & $\begin{array}{l}\text { 1. Greater number of oocytes } \\
\text { recovered during pick up }\end{array}$ & \multirow[t]{3}{*}{$\begin{array}{l}\text { Ciotta } \\
\text { et al. [127] }\end{array}$} \\
\hline & & & & & $\begin{array}{l}\text { 2. Greater number of oocytes with } \\
\text { score S1 }\end{array}$ & \\
\hline & & & & & $\begin{array}{l}\text { 3. Reduced number of immature } \\
\text { oocytes (vesicles germ and } \\
\text { degenerated oocytes) }\end{array}$ & \\
\hline \multirow[t]{2}{*}{ Melatonin } & \multirow{2}{*}{$\begin{array}{l}\text { Follicular fluid } \\
\text { sampled } \\
\text { during oocyte } \\
\text { retrieval } \\
\text { during IVF-ET }\end{array}$} & \multirow{2}{*}{$\begin{array}{l}\text { Women with } \\
\text { prior failure of } \\
\text { IVF-ET cycle } \\
\text { and who are } \\
\text { attempting } \\
\text { IVF-ET again } \\
(\mathrm{n}=115)\end{array}$} & \multirow{2}{*}{$\begin{array}{l}3 \text { mg melatonin }(n=56) \\
\text { given on the } 5 \text { th day of } \\
\text { the previous menstrual } \\
\text { cycle until the day of } \\
\text { oocyte retrieval }\end{array}$} & \multirow{2}{*}{$\begin{array}{l}\text { Without } \\
\text { melatonin } \\
\text { treatment } \\
(\mathrm{n}=59)\end{array}$} & $\begin{array}{l}\text { 1. Improved fertilization rate } \\
\text { compared to previous IVF-ET cycle }\end{array}$ & \multirow[t]{2}{*}{$\begin{array}{l}\text { Tamura } \\
\text { et al. [128] }\end{array}$} \\
\hline & & & & & 2. Improved oocyte quality & \\
\hline \multirow[t]{4}{*}{ Melatonin } & \multirow[t]{4}{*}{$\begin{array}{l}\text { Prospective, } \\
\text { randomized }\end{array}$} & \multirow{4}{*}{$\begin{array}{l}\text { Women } \\
\text { with primary } \\
\text { infertility } \\
\text { undergoing } \\
\text { IVF-ET cycles } \\
(n=85)\end{array}$} & \multirow{4}{*}{$\begin{array}{l}3 \text { mg melatonin }(n=40) \\
\text { administered } \\
\text { continuously from day of } \\
\text { GnRH }\end{array}$} & \multirow[t]{4}{*}{$\begin{array}{l}\text { No treatment } \\
(n=45)\end{array}$} & $\begin{array}{l}\text { 1. Higher percentage of morphologically } \\
\text { mature oocytes retrieved (MIl oocytes) }\end{array}$ & \multirow[t]{4}{*}{$\begin{array}{l}\text { Batioglu } \\
\text { et al. [129] }\end{array}$} \\
\hline & & & & & $\begin{array}{l}\text { 2. Higher mean number of top quality } \\
\text { (class I) embryos }\end{array}$ & \\
\hline & & & & & 3. No improvement in fertilization rates & \\
\hline & & & & & $\begin{array}{l}\text { 4. Higher tendency of clinical pregnancy } \\
\text { rate (not statistically significant) }\end{array}$ & \\
\hline \multirow[t]{2}{*}{ Melatonin } & \multirow[t]{2}{*}{$\begin{array}{l}\text { Prospective, } \\
\text { randomized }\end{array}$} & \multirow{2}{*}{$\begin{array}{l}\text { IVF patients } \\
\text { with disturbed } \\
\text { sleep (insomnia) } \\
\text { who were } \\
\text { undergoing } \\
\text { IVF-ET }(n=60)\end{array}$} & \multirow{2}{*}{$\begin{array}{l}3 \text { g melatonin }(n=30) \\
\text { given } 3 \text { rd to the } 5 \text { th day } \\
\text { of the previous menstrual } \\
\text { cycle until the } h C G \\
\text { injection day of the } \\
\text { controlled ovarian } \\
\text { hyperstimulation }\end{array}$} & \multirow[t]{2}{*}{$\begin{array}{l}\text { No treatment } \\
(\mathrm{n}=30)\end{array}$} & $\begin{array}{l}\text { 1. Higher mean number of the retrieved } \\
\text { oocytes, mean Mll oocyte counts, and G1 } \\
\text { embryo ratio }\end{array}$ & \multirow[t]{2}{*}{$\begin{array}{l}\text { Eryilmaz } \\
\text { et al. [130] }\end{array}$} \\
\hline & & & & & 2. No change in sleeping status & \\
\hline
\end{tabular}




\section{Table 3 Study outcomes involving oral supplementation of various antioxidants in women (Continued)}

\begin{tabular}{|c|c|c|c|}
\hline $\begin{array}{l}\text { Melatonin + } \\
\text { myo-inositol + } \\
\text { folic acid }\end{array}$ & $\begin{array}{l}\text { Prospective, } \\
\text { randomized }\end{array}$ & $\begin{array}{l}\text { Women } \\
\text { undergoing } \\
\text { IVF cycles } \\
(n=65)\end{array}$ & $\begin{array}{l}3 \mathrm{~g} \text { melatonin }+4 \mathrm{~g} \\
\text { myo-inositol }+200 \mathrm{mg} \\
\text { folic acid }(\mathrm{n}=32) \\
\text { administered } \\
\text { continuously from } \\
\text { day of GnRH }\end{array}$ \\
\hline
\end{tabular}

Melatonin + Prospective, myo-inositol + longitudinal, folic acid cohort

\author{
Women with \\ failed IVF cycle \\ (due to poor \\ oocyte quality) \\ who were \\ undergoing a \\ new IVF cycle \\ $3 \mathrm{mg}$ melatonin $+4 \mathrm{~g}$ \\ myo-inositol $+400 \mathrm{mcg}$ \\ folic acid $\times 3$ months \\ $(n=46)$
}

$4 \mathrm{~g}$ myo-
inositol + folic
acid $(n=33)$

Prior cycle of the same women but without

\author{
1. Greater mean number of mature \\ oocytes (and lower mean number \\ of immature oocytes) \\ 2. Higher mean number of top quality \\ embryos (class 1 and 2) \\ 3. No improvement in fertilization rates \\ 4. Higher tendency of clinical pregnancy \\ rate and implantation rate (not \\ statistically significant)
} treatment
1. Higher number of morphologically mature oocytes retrieved (MII oocytes)

2. Higher total number of embryo transferred and higher number of top quality (score 1 \& 2) embryo transferred

3. Increased fertilization rate achieved spontaneous pregnancy [105]. Based on their findings, it seems that a combination of vitamin $E$ and selenium had a more significant impact on motility compared to morphology.

Besides selenium, vitamin $\mathrm{E}$ is often administered in combination with vitamin $\mathrm{C}$, another chain breaking antioxidant. An initial RCT reported that sperm parameters did not change after co-supplementation with vitamins $\mathrm{E}$ and $C$ [106]. However, subsequent observational studies in men with poor sperm DNA integrity showed that supplementation with both vitamins $\mathrm{E}$ and $\mathrm{C}$ resulted in fewer spermatozoa with fragmented DNA [107,108], as well as higher implantation and clinical pregnancy rates [108].

Vitamin C Vitamin C (L-ascorbic acid, ascorbate) is a water-soluble, naturally-occurring, chain-breaking antioxidant. It is unstable, easily oxidized and perishable in high temperatures [153]. Ascorbic acid taken as dietary intake $[154,155]$ or oral therapy, improves spermatozoa quality $[109,110]$. In a large, placebo-controlled, double blind RCT, vitamin $\mathrm{C}$ supplementation for a period of 14 days starting on the day of follicle aspiration in women undergoing IVF-ET showed no improvement in clinical pregnancy or implantation rates [125]. However, smaller prospective studies showed that oral vitamin $C$ supplementation in women, either undergoing IVF-ET treatment [123] or with luteal phase defects [124], lead to increased pregnancy rates. Addition of vitamin $C$ in cryomedia improved motility [62] and reduced DNA damage [61] in post-thaw spermatozoa. Similarly, vitamin C supplemented culture media reduced lipid peroxidation and DNA damage, while improving spermatozoa motility and viability [60].

Vitamin B - folic acid B vitamins form a group of water soluble antioxidants. Folate (vitamin B9) is the natural dietary form, while folic acid is its synthetic equivalent.
Folate levels in seminal plasma are higher than in serum and in fertile men compared to infertile men [156,157]. Similarly, fertile men were found to have higher seminal zinc levels compared to infertile men [158]. As it has been observed that zinc deficiency decreases the absorption and metabolism of folate, most studies related to folate is combined with zinc supplementation. An essential trace element, zinc acts as a ROS-scavenger and regulates sperm motility [159]. In men with asthenozoospermia, intake of zinc sulphate (500 mg for 3 months) improved spermatozoa quality (count, progressive motility and fertilizing capacity) and reduced the incidence of antisperm antibodies [160].

Double-blind, placebo-controlled, RCTs investigating the effects of combined folic acid and zinc sulphate oral treatment in infertile men report an increase in sperm concentration $[111,112]$, but not in those with severe oligoasthenoteratozoospermia (OAT) [113]. Among varicocele patients who sought surgical intervention, combined therapy of folic acid and zinc sulphate improved sperm parameters and consequently varicocelectomy outcome [114]. In infertile women with PCOS undergoing ovulation induction for IVF/ICSI, oral therapy of myo-inositol (a component of the vitamin B family) and folic acid reduced the number of immature oocytes during pick up [126,127].

Coenzyme $\mathbf{Q}_{10}$ Coenzyme $\mathrm{Q}_{10}$ is a vitamin-like, lipid soluble substance present in most eukaryotic cells as it forms part of the the mitochondrial respiratory chain. Coenzyme $\mathrm{Q}_{10}$ may also be present in its oxidized (ubiquinone) or reduced form (ubiquinol) [161]. Results of a systematic review and meta-analysis on coenzyme $Q_{10}$ therapy in male infertility show that oral supplementation with coenzyme $Q_{10}$ increased seminal coenzyme $Q_{10}$ levels, spermatozoa concentration and motility. However, there was no increase in pregnancy rates while data 
for live births was lacking [115]. In 4 double-blind, placebo-controlled RCTs using coenzyme $\mathrm{Q}_{10}$ or ubiquinol therapy in men with idiopathic infertility, study outcomes also reported of lower lipid peroxidation and oxidative stress levels in seminal plasma [116,117], increase in seminal enzymatic antioxidant activity $[116,117]$ and ubiquinol (a potent antioxidant) levels [119]. Prospective studies on coenzyme $\mathrm{Q}_{10}$ intake in men with idiopathic infertility reported of improved acrosome reaction [120] and pregnancy rates [121]. In infertile men with prior failed IVF/ICSI, coenzyme $\mathrm{Q}_{10}$ supplementation increased fertilization rates in the subsequent cycle [63]. The group also found that adding coenzyme $\mathrm{Q}_{10}$ into media with asthenozoopermic spermatozoa increased spermatozoa motility [63].

\section{Hormones}

Melatonin Melatonin, a powerful antioxidant secreted by the pineal gland, is present in follicular fluid and semen. Melatonin also activates the primary enzymatic antioxidants (SOD, catalase, GPx) [162]. Interestingly the concentration of melatonin in the pre-ovulatory follicle is higher than normal plasma melatonin levels [163]. Intrafollicular melatonin levels also inversely correlated to 8-OHdG and thus degenerate oocytes [164]. In several prospective randomized studies in infertile women undergoing IVF-ET cycles, continuous oral melatonin supplementation, starting from the previous menstrual cycle until ovarian stimulation, improved oocyte quality, increased the number of mature MII oocytes retrieved and resulted in a better ratio of top quality embryos $[129,130,164]$. In other prospective studies, melatonin was given along with myo-inositol and folic acid in women planning for IVF treatment, which also resulted in higher number of mature oocytes and top quality embryos $[131,132]$. There was a tendency for higher clinical pregnancy and implantation rates (although statistically insignificant) $[129,131]$, while fertilization rates were reported to be either higher $[132,164]$ or without improvement in $[129,131]$. However, a systematic review and meta-analysis of RCTs on melatonin supplementation in women undergoing controlled ovarian stimulation for assisted conception concluded that the included trials provided low quality evidence on the parameters examined [165]. In experimental in vitro studies, spermatozoa from healthy men incubated with melatonin showed improved motility, viability $[64,65]$ and higher ratio of spermatozoa with normal morphology [64].

\section{Other antioxidative substances}

Trace element supplementation has shown to improve sperm quality. For example, in vitro zinc supplementation to sperm media, either alone or in combination with other antioxidants (as previously discussed), reduced sperm DNA fragmentation [166,167], and loss of motility [167].
Addition of zinc to cryomedia also protects against post-thaw loss of spermatozoa function and sperm DNA damage [168]. In a large double blind placebocontrolled RCT involving infertile men with idiopathic OAT (iOAT) combined oral intake of selenium and $\mathrm{N}$-acetylcysteine correlated positively with spermatozoa quality. The additive effects were significantly better when compared to either selenium or N-acetyl-cysteine intake [169]. Besides trace elements, other antioxidants such as L-Carnitine also play a role in the enhancement of sperm parameters. Derived from lysine, L-Carnitine is a naturally-occurring molecule [170] that scavenges ROS. A systemic review and meta-analysis of 9 RCTs concluded that oral supplementation with L-carnitine or L-acetyl-carnitine improves total sperm motility and pregnancy rates [171]. In two separate studies, it was shown that the in vitro addition of L-carnitine to the culture media not only improved oocyte chromosomal structure and reduced embryo apoptosis [66], but also improved blastocyst development rate [67].

\section{Conclusions}

A Cochrane review on antioxidant intake in male partners of couples undergoing ART (34 trials, 2876 couples) reported increased pregnancy rate (15 trials, 964 couples, 96 pregnancies) (pooled odds ratio (OR) 4.18, 95\% CI 2.65-6.59; $\left.\mathrm{P}<0.00001, \mathrm{I}^{2}=0 \%\right)$ and increased live births (3 studies, 214 couples, 20 live births) (pooled OR 4.85, 95\% CI 1.92-12.24); $\mathrm{P}=0.0008, \mathrm{I}^{2}=0 \%$ ) in men taking oral antioxidants [172]. On the other hand, a Cochrane review on oral antioxidant supplementation in women seeking IVF/ICSI (28 trials, 3548 women) reported of very low quality evidence indicating that antioxidant intake was neither associated with increased pregnancy rate (13 trials, 2441 women) (OR 1.30, 95\% CI 0.92-1.85; $\mathrm{P}=0.14$, $\left.\mathrm{I}^{2}=55 \%\right)$ nor with live birth rate (2 trials, 97 women) (OR 1.25, 95\% CI 0.19-8.26; $\mathrm{P}=0.82, \mathrm{I}^{2}=75 \%$ ). However, data from 3 trials (276 women) showed that pentoxifylline was associated with increased clinical pregnancy rates (OR 2.03, 95\% CI 1.19-3.44, $\mathrm{P}=0.009, \mathrm{I}^{2}=0 \%$ ) in subfertile women [173]. Both these reviews outlined the need for better quality evidence that would allow for a more definitive verdict on the usefulness of oral antioxidant therapy in the ART population.

Along these lines, further large, well-designed randomized controlled clinical trials on oral supplementation of antioxidants is required in order to give stronger evidence and determine more conclusively regarding the safety and efficacy of antioxidant therapy in improving gamete quality in infertile males and females as well as couples seeking ART. Similarly, the use of antioxidants in vitro in the clinical laboratory setting during ART procedures should also be considered, alongside improvement of ART techniques and optimization of the laboratory environment. As even some of the studies that form the basis for the previously 
listed Cochrane reviews are subject to significant heterogeneity it is important to note that unrestricted recommendation of antioxidant supplements could even be hazardous to patients.

Undeniably, excessive ROS leading to oxidative stress conditions has a serious impact on the outcome of assisted reproduction, leading to lower fertilization, implantation and pregnancy rates. As highlighted in this review, ART procedures in vitro presents with many avenues for ROS and oxidative stress development, which would negatively impair gamete/embryo quality and consequently reduce ART success. While the generation of ROS during ART steps cannot completely be avoided, practical strategies that minimize potential ROS-inducing factors during the ART procedures, as portrayed in this paper, are worth exploring.

In conclusion, prophylactic oral antioxidant therapy and supplementation of medium for culture, incubation/ handling and cryopreservation can possibly help improve gamete quality and fortify the developing embryo. However, the appropriate antioxidants and dosages (whether as a sole compound or as a combination) suitable for different forms of infertility issues still remain an ongoing area of research.

\section{Abbreviations}

ART: Assisted reproductive technology; $\mathrm{CoQ}_{10}$ : Coenzyme $\mathrm{Q}_{10}$; $\mathrm{GnRH}$ : Gonadotropin releasing hormone; GSH: Reduced Glutathione; GPx: Glutathione peroxidase; GR: Glutathione reductase; GST: Glutathione-S transferase; GSSG: Gluthathione disulphide; hCG: Human chorionic gonadotropin; IUI: Intrauterine insemination; IVF: In vitro fertilization; IVF-ET: In vitro fertilization-embryo transfer; ICSI: Intracytoplasmic sperm injection; LPO: Lipid peroxidation; OAT: Oligoasthenoteratozoospermia; OS: Oxidative stress; PCOS: Polycystic ovarian syndrome; RCTs: Randomized controlled trials; ROS: Reactive oxygen species; SOD: Superoxide dismutase.

\section{Competing interests}

The authors declare that they have no competing interests.

\section{Authors' contributions}

AA conceived of the study, participated in its design and coordination, and reviewed the manuscript. DD participated in the design of the study and drafted the manuscript. SSDP participated in the design of the study and helped to draft the manuscript. All authors have read and approved the final manuscript.

\section{Author details}

${ }^{1}$ Center for Reproductive Medicine, Glickman Urological \& Kidney Institute Cleveland Clinic, Cleveland, OH 44195, USA. ${ }^{2}$ Discipline of Physiology, Faculty of Medicine, MARA University of Technology, Sungai Buloh, Selangor, 47000, Malaysia. ${ }^{3}$ Division of Medical Physiology, Faculty of Medicine and Health Sciences, Stellenbosch University, Tygerberg 7505, South Africa.

Received: 12 August 2014 Accepted: 6 November 2014

Published: 24 November 2014

\section{References}

1. Zegers-Hochschild F, Adamson GD, de Mouzon J, Ishihara O, Mansour R, Nygren K, Sullivan E, van der Poel S, International Committee for Monitoring Assisted Reproductive T, World Health O: The International Committee for Monitoring Assisted Reproductive Technology (ICMART) and the World Health Organization (WHO) Revised Glossary on ART Terminology, 2009. Hum Reprod 2009, 24:2683-2687.

2. Sharlip ID, Jarow JP, Belker AM, Lipshultz LI, Sigman M, Thomas AJ, Schlegel PN, Howards SS, Nehra A, Damewood MD, Overstreet JW, Sadovsky R: Best practice policies for male infertility. Fertil Steril 2002, 77:873-882.
3. Gupta S, Sekhon L, Kim Y, Agarwal A: The role of oxidative stress and antioxidants in assisted reproduction. Curr Women's Health Rev 2010, 6:227-238.

4. Lampiao F: Free radicals generation in an in vitro fertilization setting and how to minimize them. World J Obstet Gynecol 2012, 1:29-34.

5. du Plessis SS, Makker K, Desai NR, Agarwal A: Impact of oxidative stress on IVF. Expet Rev Obstet Gynecol 2008, 3:539-554.

6. Rakhit M, Gokul SR, Agarwal A, du Plessis SS: Antioxidant strategies to overcome OS in IVF-Embryo transfer. In Studies on Women's Health. Humana Press; 2013:237-262.

7. Agarwal A, Allamaneni SS: Role of free radicals in female reproductive diseases and assisted reproduction. Reprod Biomed Online 2004, 9:338-347.

8. Sharma RK, Agarwal A: Role of reactive oxygen species in male infertility. Urology 1996, 48:835-850.

9. Hammadeh ME, Al Hasani S, Rosenbaum P, Schmidt W, Fischer Hammadeh C: Reactive oxygen species, total antioxidant concentration of seminal plasma and their effect on sperm parameters and outcome of IVF/ICSI patients. Arch Gynecol Obstet 2008, 277:515-526.

10. Aitken RJ: Free radicals, lipid peroxidation and sperm function. Reprod Fertil Dev 1995, 7:659-668.

11. Agarwal A, Said TM, Bedaiwy MA, Banerjee J, Alvarez JG: Oxidative stress in an assisted reproductive techniques setting. Fertil Steril 2006, 86:503-512.

12. Saalu LC: The incriminating role of reactive oxygen species in idiopathic male infertility: an evidence based evaluation. Pakistan J Biol Sci 2010, 13:413-422.

13. Gupta S, Malhotra N, Sharma D, Chandra A, Agarwal A: Oxidative stress and its role in female infertility and assisted reproduction: clinical implications. Int J Fertil Steril 2009, 2:147-164.

14. de Lamirande E, Gagnon C: A positive role for the superoxide anion in triggering hyperactivation and capacitation of human spermatozoa. Int J Androl 1993, 16:21-25.

15. Agarwal A, Virk G, Ong C, du Plessis SS: Effect of oxidative stress on male reproduction. World J Men's Health 2014, 32:1-17.

16. Kothari S, Thompson A, Agarwal A, du Plessis SS: Free radicals: their beneficial and detrimental effects on sperm function. Indian J Exp Biol 2010, 48:425-435.

17. Tremellen K: Oxidative stress and male infertility-a clinical perspective. Hum Reprod Update 2008, 14:243-258.

18. Aitken RJ, Fisher HM, Fulton N, Gomez E, Knox W, Lewis B, Irvine S: Reactive oxygen species generation by human spermatozoa is induced by exogenous NADPH and inhibited by the flavoprotein inhibitors diphenylene iodonium and quinacrine. Mol Reprod Dev 1997, 47:468-482.

19. Rengan AK, Agarwal A, van der Linde M, du Plessis SS: An investigation of excess residual cytoplasm in human spermatozoa and its distinction from the cytoplasmic droplet. Reprod Biol Endocrinol 2012, 10:92.

20. Whittington K, Ford WC: Relative contribution of leukocytes and of spermatozoa to reactive oxygen species production in human sperm suspensions. Int J Androl 1999, 22:229-235.

21. Kessopoulou E, Tomlinson MJ, Barratt CL, Bolton AE, Cooke ID: Origin of reactive oxygen species in human semen: spermatozoa or leucocytes? J Reprod Fertil 1992, 94:463-470.

22. Saleh RA, Agarwal A, Nada EA, El-Tonsy MH, Sharma RK, Meyer A, Nelson DR, Thomas AJ: Negative effects of increased sperm DNA damage in relation to seminal oxidative stress in men with idiopathic and male factor infertility. Fertil Steril 2003, 79(Suppl 3):1597-1605.

23. Kroese AC, de Lange NM, Collins J, Evers JL: Surgery or embolization for varicoceles in subfertile men. Cochrane Database Syst Rev 2012, 10, CD000479.

24. Shiraishi K, Matsuyama $H$, Takihara $H$ : Pathophysiology of varicocele in male infertility in the era of assisted reproductive technology. Int J Urol: Offic J Jpn Urol Assoc 2012, 19:538-550.

25. Agarwal A, Prabakaran S, Allamaneni SS: Relationship between oxidative stress, varicocele and infertility: a meta-analysis. Reprod Biomed Online 2006, 12:630-633.

26. Agarwal A, Gupta S, Abdel-Razek H, Krajcir N, Athayde K: Impact of oxidative stress on gametes and embryos in an ART Laboratory. Clin Embryologist 2006, 9:5-22.

27. Esfandiari N, Falcone T, Agarwal A, Attaran M, Nelson DR, Sharma RK: Protein supplementation and the incidence of apoptosis and oxidative stress in mouse embryos. Obstet Gynecol 2005, 105:653-660.

28. Seino T, Saito H, Kaneko T, Takahashi T, Kawachiya S, Kurachi H: Eight-hydroxy-2'-deoxyguanosine in granulosa cells is correlated with 
the quality of oocytes and embryos in an in vitro fertilization-embryo transfer program. Fertil Steril 2002, 77:1184-1190.

29. Zhuo L, Kimata K: Cumulus oophorus extracellular matrix: its construction and regulation. Cell Struct Funct 2001, 26:189-196.

30. Huang Z, Wells D: The human oocyte and cumulus cells relationship: new insights from the cumulus cell transcriptome. Mol Hum Reprod 2010, 16:715-725

31. Matos L, Stevenson D, Gomes F, Silva-Carvalho JL, Almeida H: Superoxide dismutase expression in human cumulus oophorus cells. Mol Hum Reprod 2009, 15:411-419.

32. Attaran M, Pasqualotto E, Falcone T, Goldberg JM, Miller KF, Agarwal A, Sharma RK: The effect of follicular fluid reactive oxygen species on the outcome of in vitro fertilization. Int J Fertil Womens Med 2000, 45:314-320.

33. Pasqualotto EB, Agarwal A, Sharma RK, Izzo VM, Pinotti JA, Joshi NJ, Rose BI: Effect of oxidative stress in follicular fluid on the outcome of assisted reproductive procedures. Fertil Steril 2004, 81:973-976.

34. Bedaiwy MA, Elnashar SA, Goldberg JM, Sharma R, Mascha EJ, Arrigain S, Agarwal A, Falcone T: Effect of follicular fluid oxidative stress parameters on intracytoplasmic sperm injection outcome. Gynecol Endocrinol 2012, 28:51-55.

35. Jana SK KNB, Chattopadhyay R, Chakravarty B, Chaudhury K: Upper control limit of reactive oxygen species in follicular fluid beyond which viable embryo formation is not favorable. Reprod Toxicol 2010, 29:447-451.

36. Das S, Chattopadhyay R, Ghosh S, Ghosh S, Goswami SK, Chakravarty BN, Chaudhury K: Reactive oxygen species level in follicular fluid-embryo quality marker in IVF? Hum Reprod 2006, 21:2403-2407.

37. Guerin P, El Mouatassim S, Menezo Y: Oxidative stress and protection against reactive oxygen species in the pre-implantation embryo and its surroundings. Hum Reprod Update 2001, 7:175-189.

38. Gott AL, Hardy K, Winston RM, Leese HJ: Non-invasive measurement of pyruvate and glucose uptake and lactate production by single human preimplantation embryos. Hum Reprod 1990, 5:104-108.

39. Agarwal A, Saleh RA, Bedaiwy MA: Role of reactive oxygen species in the pathophysiology of human reproduction. Fertil Steril 2003, 79:829-843.

40. Goto Y, Noda Y, Mori T, Nakano M: Increased generation of reactive oxygen species in embryos cultured in vitro. Free Radic Biol Med 1993, 15(1):69-75.

41. Li R, Liu Y, Pedersen HS, Callesen H: Effect of ambient light exposure of media and embryos on development and quality of porcine parthenogenetically activated embryos. Zygote 2014, 1-6 [Epub ahead of print].

42. Ottosen LD, Hindkjaer J, Ingerslev J: Light exposure of the ovum and preimplantation embryo during ART procedures. J Assist Reprod Genet 2007, 24:99-103

43. Squirrell JM, Wokosin DL, White JG, Bavister BD: Long-term two-photon fluorescence imaging of mammalian embryos without compromising viability. Nat Biotechnol 1999, 17:763-767.

44. Hockberger PE, Skimina TA, Centonze VE, Lavin C, Chu S, Dadras S, Reddy JK, White JG: Activation of flavin-containing oxidases underlies light-induced production of $\mathrm{H} 2 \mathrm{O} 2$ in mammalian cells. Proc Natl Acad Sci U S A 1999, 96:6255-6260

45. Oh SJ, Gong SP, Lee ST, Lee EJ, Lim JM: Light intensity and wavelength during embryo manipulation are important factors for maintaining viability of preimplantation embryos in vitro. Fertil Steril 2007, 88:1150-1157

46. Noda Y, Goto Y, Umaoka Y, Shiotani M, Nakayama T, Mori T: Culture of human embryos in alpha modification of Eagle's medium under low oxygen tension and low illumination. Fertil Steril 1994, 62:1022-1027.

47. Takenaka M, Horiuchi $T$, Yanagimachi R: Effects of light on development of mammalian zygotes. Proc Natl Acad Sci U S A 2007, 104:14289-14293.

48. Moshkdanian G, Nematollahi-Mahani SN, Pouya F, Nematollahi-Mahani A Antioxidants rescue stressed embryos at a rate comparable with co-culturing of embryos with human umbilical cord mesenchymal cells. J Assist Reprod Genet 2011, 28:343-349.

49. Umaoka Y, Noda Y, Nakayama T, Narimoto K, Mori T, Iritani A: Effect of visual light on in vitro embryonic development in the hamster. Theriogenology 1992, 38:1043-1054.

50. Takahashi M, Saka N, Takahashi H, Kanai Y, Schultz RM, Okano A: Assessment of DNA damage in individual hamster embryos by comet assay. Mol Reprod Dev 1999, 54:1-7.

51. Shahar S, Wiser A, Ickowicz D, Lubart R, Shulman A, Breitbart H: Light-mediated activation reveals a key role for protein kinase $A$ and sarcoma protein kinase in the development of sperm hyper-activated motility. Hum Reprod 2011, 26:2274-2282.

52. Jin J, Jin N, Zheng H, Ro S, Tafolla D, Sanders KM, Yan W: Catsper3 and Catsper4 are essential for sperm hyperactivated motility and male fertility in the mouse. Biol Reprod 2007, 77:37-44.

53. Ho HC, Suarez SS: Hyperactivation of mammalian spermatozoa: function and regulation. Reproduction 2001, 122:519-526.

54. Orsi NM, Leese HJ: Protection against reactive oxygen species during mouse preimplantation embryo development: role of EDTA, oxygen tension, catalase, superoxide dismutase and pyruvate. Mol Reprod Dev 2001, 59:44-53.

55. Nasr-Esfahani MH, Winston NJ, Johnson MH: Effects of glucose, glutamine, ethylenediaminetetraacetic acid and oxygen tension on the concentration of reactive oxygen species and on development of the mouse preimplantation embryo in vitro. J Reprod Fertil 1992, 96:219-231.

56. Sikka SC: Role of oxidative stress and antioxidants in andrology and assisted reproductive technology. J Androl 2004, 25:5-18.

57. Kalthur G, Raj S, Thiyagarajan A, Kumar S, Kumar P, Adiga SK: Vitamin E supplementation in semen-freezing medium improves the motility and protects sperm from freeze-thaw-induced DNA damage. Fertil Steril 2011, 95:1149-1151

58. Taylor K, Roberts P, Sanders K, Burton P: Effect of antioxidant supplementation of cryopreservation medium on post-thaw integrity of human spermatozoa. Reprod Biomed Online 2009, 18:184-189.

59. Keshtgar S, Fanaei H, Bahmanpour S, Azad F, Ghannadi A, Kazeroni M: In vitro effects of alpha-tocopherol on teratozoospermic semen samples. Andrologia 2012, 44(Suppl 1):721-727.

60. Fanaei H, Khayat S, Halvaei I, Ramezani V, Azizi Y, Kasaeian A, Mardaneh J, Parvizi MR, Akrami M: Effects of ascorbic acid on sperm motility, viability, acrosome reaction and DNA integrity in teratozoospermic samples. Iranian J Reprod Med 2014, 12:103-110.

61. Branco CS, Garcez ME, Pasqualotto FF, Erdtman B, Salvador M: Resveratrol and ascorbic acid prevent DNA damage induced by cryopreservation in human semen. Cryobiology 2010, 60:235-237.

62. Jenkins TG, Aston KI, Carrell DT: Supplementation of cryomedium with ascorbic acid-2-glucoside (AA2G) improves human sperm post-thaw motility. Fertil Steril 2011, 95:2001-2004.

63. Lewin $\mathrm{A}$, Lavon $\mathrm{H}$ : The effect of coenzyme $\mathrm{Q} 10$ on sperm motility and function. Mol Aspects Med 1997, 18(Suppl):S213-S219.

64. Ortiz A, Espino J, Bejarano I, Lozano GM, Monllor F, Garcia JF, Pariente JA, Rodriguez AB: High endogenous melatonin concentrations enhance sperm quality and short-term in vitro exposure to melatonin improves aspects of sperm motility. J Pineal Res 2011, 50:132-139.

65. du Plessis SS, Hagenaar K, Lampiao F: The in vitro effects of melatonin on human sperm function and its scavenging activities on NO and ROS. Andrologia 2010, 42:112-116.

66. Mansour G, Abdelrazik H, Sharma RK, Radwan E, Falcone T, Agarwal A: $\mathrm{L}$-carnitine supplementation reduces oocyte cytoskeleton damage and embryo apoptosis induced by incubation in peritoneal fluid from patients with endometriosis. Fertil Steril 2009, 91:2079-2086.

67. Abdelrazik H, Sharma R, Mahfouz R, Agarwal A: L-carnitine decreases DNA damage and improves the in vitro blastocyst development rate in mouse embryos. Fertil Steril 2009, 91:589-596.

68. Will MA, Clark NA, Swain JE: Biological pH buffers in IVF: help or hindrance to success. J Assist Reprod Genet 2011, 28:711-724.

69. Bagger PV, Byskov AG, Christiansen MD: Maturation of mouse oocytes in vitro is influenced by alkalization during their isolation. J Reprod Fertil 1987, 80:251-255.

70. Suzuki N, Mittler R: Reactive oxygen species and temperature stresses: a delicate balance between signaling and destruction. Physiol Plant 2006, 126:45-51.

71. Ferguson WJ, Braunschweiger KI, Braunschweiger WR, Smith JR, McCormick JJ, Wasmann CC, Jarvis NP, Bell DH, Good NE: Hydrogen ion buffers for biological research. Anal Biochem 1980, 104:300-310.

72. Larkindale J, Knight MR: Protection against heat stress-induced oxidative damage in Arabidopsis involves calcium, abscisic acid, ethylene, and salicylic acid. Plant Physiol 2002, 128:682-695.

73. Calzi F, Papaleo E, Rabellotti E, Ottolina J, Vailati S, Vigano P, Candiani M: Exposure of embryos to oxygen at low concentration in a cleavage stage transfer program: reproductive outcomes in a time-series analysis. Clin Lab 2012, 58:997-1003. 
74. Cohen J, Gilligan A, Esposito W, Schimmel T, Dale B: Ambient air and its potential effects on conception in vitro. Hum Reprod 1997, 12:1742-1749.

75. Bontekoe S, Mantikou E, van Wely M, Seshadri S, Repping S, Mastenbroek S: Low oxygen concentrations for embryo culture in assisted reproductive technologies. Cochrane Database Syst Rev 2012, 7, CD008950.

76. Kovacic B, Sajko MC, Vlaisavljevic V: A prospective, randomized trial on the effect of atmospheric versus reduced oxygen concentration on the outcome of intracytoplasmic sperm injection cycles. Fertil Steril 2010, 94:511-519.

77. Kovacic B, Vlaisavljevic V: Influence of atmospheric versus reduced oxygen concentration on development of human blastocysts in vitro: a prospective study on sibling oocytes. Reprod Biomed Online 2008, 17:229-236.

78. Gomes Sobrinho DB, Oliveira JB, Petersen CG, Mauri AL, Silva LF, Massaro FC, Baruffi RL, Cavagna M, Franco JG Jr: IVF/ICSI outcomes after culture of human embryos at low oxygen tension: a meta-analysis. Reprod Biol Endocrinol 2011, 9:143.

79. Shekarriz M, DeWire DM, Thomas AJ Jr, Agarwal A: A method of human semen centrifugation to minimize the iatrogenic sperm injuries caused by reactive oxygen species. Eur Urol 1995, 28:31-35.

80. Henkel RR, Schill WB: Sperm preparation for ART. Reprod Biol Endocrinol 2003, 1:108.

81. McKinney KA, Lewis SE, Thompson W: The effects of pentoxifylline on the generation of reactive oxygen species and lipid peroxidation in human spermatozoa. Andrologia 1996, 28:15-20.

82. Lampiao F, Strijdom H, Du Plessis SS: Effects of sperm processing techniques involving centrifugation on nitric oxide, reactive oxygen species generation and sperm function. Open Androl J 2010, 2:1-5.

83. Agarwal A, Said TM: Role of sperm chromatin abnormalities and DNA damage in male infertility. Hum Reprod Update 2003, 9:331-345.

84. Gandini L, Lombardo F, Paoli D, Caponecchia L, Familiari G, Verlengia C, Dondero F, Lenzi A: Study of apoptotic DNA fragmentation in human spermatozoa. Hum Reprod 2000, 15:830-839.

85. Pegg DE: Principles of cryopreservation. Methods Mol Biol 2007, 368:39-57.

86. Di Santo M, Tarozzi N, Nadalini M, Borini A: Human sperm cryopreservation: update on techniques, effect on DNA integrity, and implications for ART. Adv Urol 2012, 2012:854837.

87. Thomson LK, Fleming SD, Aitken RJ, De luliis GN, Zieschang JA, Clark AM: Cryopreservation-induced human sperm DNA damage is predominantly mediated by oxidative stress rather than apoptosis. Hum Reprod 2009, 24:2061-2070

88. Zribi N, Feki Chakroun N, El Euch H, Gargouri J, Bahloul A, Ammar Keskes L: Effects of cryopreservation on human sperm deoxyribonucleic acid integrity. Fertil Steril 2010, 93:159-166.

89. Zini A, Al-Hathal N: Antioxidant therapy in male infertility: fact or fiction? Asian J Androl 2011, 13:374-381.

90. Zribi N, Chakroun NF, Ben Abdallah F, Elleuch H, Sellami A, Gargouri J, Rebai T, Fakhfakh F, Keskes LA: Effect of freezing-thawing process and quercetin on human sperm survival and DNA integrity. Cryobiology 2012, 65:326-331.

91. Moubasher AE, El Din AM, Ali ME, El-sherif WT, Gaber HD: Catalase improves motility, vitality and DNA integrity of cryopreserved human spermatozoa. Andrologia 2013, 45(2):135-139.

92. Esteves SC, Sharma RK, Thomas AJ Jr, Agarwal A: Cryopreservation of human spermatozoa with pentoxifylline improves the post-thaw agonist-induced acrosome reaction rate. Hum Reprod 1998, 13:3384-3389.

93. Brennan AP, Holden CA: Pentoxifylline-supplemented cryoprotectant improves human sperm motility after cryopreservation. Hum Reprod 1995, 10:2308-2312.

94. Bell M, Wang R, Hellstrom WJ, Sikka SC: Effect of cryoprotective additives and cryopreservation protocol on sperm membrane lipid peroxidation and recovery of motile human sperm. J Andro/ 1993, 14:472-478.

95. Wang R, Sikka SC, Veeraragavan K, Bell M, Hellstrom WJ: Platelet activating factor and pentoxifylline as human sperm cryoprotectants. Fertil Steril 1993, 60:711-715.

96. Kalthur G, Salian SR, Keyvanifard F, Sreedharan S, Thomas JS, Kumar P, Adiga SK: Supplementation of biotin to sperm preparation medium increases the motility and longevity in cryopreserved human spermatozoa. J Assist Reprod Genet 2012, 29:631-635.

97. Nallella KP, Sharma RK, Allamaneni SS, Aziz N, Agarwal A: Cryopreservation of human spermatozoa: comparison of two cryopreservation methods and three cryoprotectants. Fertil Steril 2004, 82:913-918.
98. Sole M, Santalo J, Boada M, Clua E, Rodriguez I, Martinez F, Coroleu B, Barri PN, Veiga A: How does vitrification affect oocyte viability in oocyte donation cycles? A prospective study to compare outcomes achieved with fresh versus vitrified sibling oocytes. Hum Reprod 2013, 28:2087-2092.

99. Cobo A, Meseguer M, Remohi J, Pellicer A: Use of cryo-banked oocytes in an ovum donation programme: a prospective, randomized, controlled, clinical trial. Hum Reprod 2010, 25:2239-2246.

100. Bansal AK, Bilaspuri GS: Impacts of oxidative stress and antioxidants on semen functions. Vet Med Int 2010, 2010.

101. Kessopoulou E, Powers HJ, Sharma KK, Pearson MJ, Russell JM, Cooke ID, Barratt CL: A double-blind randomized placebo cross-over controlled trial using the antioxidant vitamin $\mathrm{E}$ to treat reactive oxygen species associated male infertility. Fertil Steril 1995, 64:825-831.

102. Suleiman SA, Ali ME, Zaki ZM, El-Malik EM, Nasr MA: Lipid peroxidation and human sperm motility: protective role of vitamin E. J Androl 1996, 17:530-537

103. Ghanem $H$, Shaeer $O$, El-Segini A: Combination clomiphene citrate and antioxidant therapy for idiopathic male infertility: a randomized controlled trial. Fertil Steril 2010, 93:2232-2235.

104. Keskes-Ammar L, Feki-Chakroun N, Rebai T, Sahnoun Z, Ghozzi H, Hammami S, Zghal K, Fki H, Damak J, Bahloul A: Sperm oxidative stress and the effect of an oral vitamin $\mathrm{E}$ and selenium supplement on semen quality in infertile men. Arch Androl 2003, 49:83-94.

105. Moslemi MK, Tavanbakhsh S: Selenium-vitamin E supplementation in infertile men: effects on semen parameters and pregnancy rate. Int J Gen Med 2011, 4:99-104

106. Rolf C, Cooper TG, Yeung CH, Nieschlag E: Antioxidant treatment of patients with asthenozoospermia or moderate oligoasthenozoospermia with high-dose vitamin C and vitamin E: a randomized, placebocontrolled, double-blind study. Hum Reprod 1999, 14:1028-1033.

107. Greco E, lacobelli M, Rienzi L, Ubaldi F, Ferrero S, Tesarik J: Reduction of the incidence of sperm DNA fragmentation by oral antioxidant treatment. J Androl 2005, 26:349-353.

108. Greco E, Romano S, lacobelli M, Ferrero S, Baroni E, Minasi MG, Ubaldi F, Rienzi L, Tesarik J: ICSI in cases of sperm DNA damage: beneficial effect of oral antioxidant treatment. Hum Reprod 2005, 20:2590-2594.

109. Dawson EB, Harris WA, Rankin WE, Charpentier LA, McGanity WJ: Effect of ascorbic acid on male fertility. Ann N Y Acad Sci 1987, 498:312-323.

110. Dawson EB, Harris WA, Teter MC, Powell LC: Effect of ascorbic acid supplementation on the sperm quality of smokers. Fertil Steril 1992, 58:1034-1039.

111. Wong WY, Merkus HM, Thomas CM, Menkveld R, Zielhuis GA, Steegers-Theunissen RP: Effects of folic acid and zinc sulfate on male factor subfertility: a double-blind, randomized, placebo-controlled trial. Fertil Steril 2002, 77:491-498.

112. Ebisch IM, Pierik FH, FH DEJ, Thomas CM, Steegers-Theunissen RP: Does folic acid and zinc sulphate intervention affect endocrine parameters and sperm characteristics in men? Int J Androl 2006, 29:339-345.

113. Raigani M, Yaghmaei B, Amirjannti N, Lakpour N, Akhondi MM, Zeraati $H$ Hajihosseinal M, Sadeghi MR: The micronutrient supplements, zinc sulphate and folic acid, did not ameliorate sperm functional parameters in oligoasthenoteratozoospermic men. Andrologia 2013, 46:956-962.

114. Azizollahi G, Azizollahi S, Babaei $H$, Kianinejad M, Baneshi MR, Nematollahi-mahani SN: Effects of supplement therapy on sperm parameters, protamine content and acrosomal integrity of varicocelectomized subjects. J Assist Reprod Genet 2013, 30:593-599.

115. Lafuente R, Gonzalez-Comadran M, Sola I, Lopez G, Brassesco M, Carreras R, Checa MA: Coenzyme Q10 and male infertility: a meta-analysis. J Assist Reprod Genet 2013, 30:1147-1156.

116. Nadjarzadeh A, Shidfar F, Amirjannati N, Vafa MR, Motevalian SA, Gohari MR, Nazeri Kakhki SA, Akhondi MM, Sadeghi MR: Effect of Coenzyme Q10 supplementation on antioxidant enzymes activity and oxidative stress of seminal plasma: a double-blind randomised clinical trial. Andrologia 2014, 46:177-183.

117. Nadjarzadeh A, Sadeghi MR, Amirjannati N, Vafa MR, Motevalian SA, Gohari MR, Akhondi MA, Yavari P, Shidfar F: Coenzyme Q10 improves seminal oxidative defense but does not affect on semen parameters in idiopathic oligoasthenoteratozoospermia: a randomized double-blind, placebo controlled trial. J Endocrinol Invest 2011, 34:e224-e228.

118. Safarinejad MR, Safarinejad S, Shafiei N, Safarinejad S: Effects of the reduced form of coenzyme Q10 (ubiquinol) on semen parameters in 
men with idiopathic infertility: a double-blind, placebo controlled, randomized study. J Urol 2012, 188:526-531.

119. Balercia G, Buldreghini E, Vignini A, Tiano L, Paggi F, Amoroso S, Ricciardo-Lamonica G, Boscaro M, Lenzi A, Littarru G: Coenzyme Q10 treatment in infertile men with idiopathic asthenozoospermia: a placebo-controlled, double-blind randomized trial. Fertil Steril 2009, 91:1785-1792

120. Safarinejad MR: Efficacy of coenzyme Q10 on semen parameters, sperm function and reproductive hormones in infertile men. J Urol 2009, 182:237-248.

121. Safarinejad MR: The effect of coenzyme Q(1)(0) supplementation on partner pregnancy rate in infertile men with idiopathic oligoasthenoteratozoospermia: an open-label prospective study. Int Urol Nephrol 2012, 44:689-700.

122. Cicek N, Eryilmaz OG, Sarikaya E, Gulerman C, Genc Y: Vitamin E effect on controlled ovarian stimulation of unexplained infertile women. J Assist Reprod Genet 2012, 29:325-328.

123. Crha I, Hruba D, Ventruba P, Fiala J, Totusek J, Visnova H: Ascorbic acid and infertility treatment. Cent Eur J Public Health 2003, 11:63-67.

124. Henmi H, Endo T, Kitajima Y, Manase K, Hata H, Kudo R: Effects of ascorbic acid supplementation on serum progesterone levels in patients with a luteal phase defect. Fertil Steril 2003, 80:459-461.

125. Griesinger G, Franke K, Kinast C, Kutzelnigg A, Riedinger S, Kulin S, Kaali SG, Feichtinger W: Ascorbic acid supplement during luteal phase in IVF. J Assist Reprod Genet 2002, 19:164-168.

126. Papaleo E, Unfer V, Baillargeon JP, Chiu TT: Contribution of myo-inositol to reproduction. Eur J Obstet Gynecol Reprod Biol 2009, 147:120-123.

127. Ciotta L, Stracquadanio M, Pagano I, Carbonaro A, Palumbo M, Gulino F: Effects of myo-inositol supplementation on oocyte's quality in PCOS patients: a double blind trial. Eur Rev Med Pharmacol Sci 2011, 15:509-514.

128. Tamura H, Nakamura Y, Terron MP, Flores $\amalg$, Manchester LC, Tan DX, Sugino N, Reiter RJ: Melatonin and pregnancy in the human. Reprod Toxicol 2008, 25:291-303.

129. Batioglu AS, Sahin U, Gurlek B, Ozturk N, Unsal E: The efficacy of melatonin administration on oocyte quality. Gynecol Endocrinol 2012, 28:91-93.

130. Eryilmaz OG, Devran A, Sarikaya E, Aksakal FN, Mollamahmutoglu L, Cicek N: Melatonin improves the oocyte and the embryo in IVF patients with sleep disturbances, but does not improve the sleeping problems. J Assist Reprod Genet 2011, 28:815-820.

131. Rizzo P, Raffone E, Benedetto V: Effect of the treatment with myo-inositol plus folic acid plus melatonin in comparison with a treatment with myo-inositol plus folic acid on oocyte quality and pregnancy outcome in IVF cycles. A prospective, clinical trial. Eur Rev Med Pharmacol Sci 2010, 14:555-561.

132. Unfer V, Raffone E, Rizzo P, Buffo S: Effect of a supplementation with myo-inositol plus melatonin on oocyte quality in women who failed to conceive in previous in vitro fertilization cycles for poor oocyte quality: a prospective, longitudinal, cohort study. Gynecol Endocrinol 2011, 27:857-861.

133. Tavilani H, Goodarzi MT, Vaisi-raygani A, Salimi S, Hassanzadeh T: Activity of antioxidant enzymes in seminal plasma and their relationship with lipid peroxidation of spermatozoa. Int Braz J 2008, 34:485-491.

134. Atig F, Raffa M, Ali HB, Abdelhamid K, Saad A, Ajina M: Altered antioxidant status and increased lipid per-oxidation in seminal plasma of tunisian infertile men. Int J Biol Sci 2012, 8:139-149.

135. Mahanta R, Gogoi A, Chaudhury PN, Roy S, Bhattacharyya IK, Sharma P. Association of oxidative stress biomarkers and antioxidant enzymatic activity in male infertility of north-East India. J Obstet Gynaecol India 2012, 62:546-550.

136. Alscher RG, Erturk N, Heath LS: Role of superoxide dismutases (SODs) in controlling oxidative stress in plants. J Exp Bot 2002, 53:1331-1341.

137. Marzec-Wroblewska U, Kaminski P, Lakota P, Szymanski M, Wasilow K, Ludwikowski G, Kuligowska-Prusinska M, Odrowaz-Sypniewska G, Stuczynski T, Michalkiewicz J: Zinc and iron concentration and SOD activity in human semen and seminal plasma. Biol Trace Elem Res 2011, 143:167-177.

138. Yan L, Liu J, Wu S, Zhang S, Ji G, Gu A: Seminal superoxide dismutase activity and its relationship with semen quality and SOD gene polymorphism. J Assist Reprod Genet 2014, 31:549-554.

139. Suzuki T, Sugino N, Fukaya T, Sugiyama S, Uda T, Takaya R, Yajima A Sasano H: Superoxide dismutase in normal cycling human ovaries: immunohistochemical localization and characterization. Fertil Steril 1999, 72:720-726.
140. Liu J, Li Y: [Effect of oxidative stress and apoptosis in granulosa cells on the outcome of IVF-ET]. Zhong nan da xue xue bao Yi xue ban = J Cent South Univ Med Sci 2010, 35:990-994.

141. Noblanc A, Kocer A, Chabory E, Vernet P, Saez F, Cadet R, Conrad M, Drevet JR: Glutathione peroxidases at work on epididymal spermatozoa: an example of the dual effect of reactive oxygen species on mammalian male fertilizing ability. J Androl 2011, 32(6):641-650.

142. Jeulin C, Soufir JC, Weber P, Laval-Martin D, Calvayrac R: Catalase activity in human spermatozoa and seminal plasma. Gamete Res 1989, 24:185-196.

143. Alrabeeah K, Alhathal N, San Gabriel M, Zini A: Influence of seminal catalase activity on IVF pregnancy. J Urol 2011, 185:e805

144. Chi HJ, Kim JH, Ryu CS, Lee JY, Park JS, Chung DY, Choi SY, Kim MH, Chun EK, Roh SI: Protective effect of antioxidant supplementation in sperm-preparation medium against oxidative stress in human spermatozoa. Hum Reprod 2008, 23:1023-1028.

145. Li Z, Lin Q, Liu R, Xiao W, Liu W: Protective effects of ascorbate and catalase on human spermatozoa during cryopreservation. J Andro/ 2010, 31:437-444.

146. Rossi T, Mazzilli F, Delfino M, Dondero F: Improved human sperm recovery using superoxide dismutase and catalase supplementation in semen cryopreservation procedure. Cell Tissue Bank 2001, 2:9-13.

147. Perkins AV: Endogenous anti-oxidants in pregnancy and preeclampsia. Aust N Z J Obstet Gynaecol 2006, 46:77-83.

148. Imai H, Nakagawa Y: Biological significance of phospholipid hydroperoxide glutathione peroxidase (PHGPx, GPx4) in mammalian cells. Free Radic Biol Med 2003, 34:145-169.

149. Crisol L, Matorras R, Aspichueta F, Exposito A, Hernandez ML, Ruiz-Larrea MB, Mendoza R, Ruiz-Sanz Jl: Glutathione peroxidase activity in seminal plasma and its relationship to classical sperm parameters and in vitro fertilization-intracytoplasmic sperm injection outcome. Fertil Steril 2012, 97:852-857.

150. Geva E, Bartoov B, Zabludovsky N, Lessing JB, Lerner-Geva L, Amit A: The effect of antioxidant treatment on human spermatozoa and fertilization rate in an in vitro fertilization program. Fertil Steril 1996, 66:430-434.

151. Mistry HD, Broughton Pipkin F, Redman CW, Poston L: Selenium in reproductive health. Am J Obstet Gynecol 2012, 206:21-30.

152. Flohe L: Selenium in mammalian spermiogenesis. Biol Chem 2007 388:987-995.

153. Iqbal K, Khan A, Khattak MMAK: Biological significance of ascorbic acid (Vitamin C) in human health - a review. Pak J Nutr 2004, 3:5-13.

154. Mendiola J, Torres-Cantero AM, Moreno-Grau JM, Ten J, Roca M, Moreno-Grau S, Bernabeu R: Food intake and its relationship with semen quality: a case-control study. Fertil Steril 2009, 91:812-818.

155. Mendiola J, Torres-Cantero AM, Vioque J, Moreno-Grau JM, Ten J, Roca M, Moreno-Grau S, Bernabeu R: A low intake of antioxidant nutrients is associated with poor semen quality in patients attending fertility clinics. Fertil Steril 2010, 93:1128-1133.

156. Wallock LM, Tamura T, Mayr CA, Johnston KE, Ames BN, Jacob RA: Low seminal plasma folate concentrations are associated with low sperm density and count in male smokers and nonsmokers. Fertil Steril 2001 75:252-259.

157. Murphy LE, Mills JL, Molloy AM, Qian C, Carter TC, Strevens H, Wide-Swensson D, Giwercman A, Levine RJ: Folate and vitamin B12 in idiopathic male infertility. Asian J Androl 2011, 13:856-861.

158. Colagar AH, Marzony ET, Chaichi MJ: Zinc levels in seminal plasma are associated with sperm quality in fertile and infertile men. Nutr Res 2009, 29:82-88.

159. Yamaguchi S, Miura C, Kikuchi K, Celino FT, Agusa T, Tanabe S, Miura T: Zinc is an essential trace element for spermatogenesis. Proc Natl Acad SCi U S A 2009, 106:10859-10864.

160. Omu AE, Dashti $\mathrm{H}$, Al-Othman S: Treatment of asthenozoospermia with zinc sulphate: andrological, immunological and obstetric outcome. Eur J Obstet Gynecol Reprod Biol 1998, 79:179-184.

161. Lanzafame FM, La Vignera S, Vicari E, Calogero AE: Oxidative stress and medical antioxidant treatment in male infertility. Reprod Biomed Online 2009, 19:638-659.

162. Mayo JC, Sainz RM, Antoli I, Herrera F, Martin V, Rodriguez C: Melatonin regulation of antioxidant enzyme gene expression. Cell Mol Life Sci 2002 59:1706-1713.

163. Nakamura $Y$, Tamura H, Takayama H, Kato H: Increased endogenous level of melatonin in preovulatory human follicles does not directly influence progesterone production. Fertil Steril 2003, 80:1012-1016. 
164. Tamura H, Takasaki A, Miwa I, Taniguchi K, Maekawa R, Asada H, Taketani T, Matsuoka A, Yamagata Y, Shimamura K, Morioka H, Ishikawa H, Reiter RJ,

Sugino N: Oxidative stress impairs oocyte quality and melatonin protects oocytes from free radical damage and improves fertilization rate. J Pineal Res 2008, 44:280-287.

165. Seko LM, Moroni RM, Leitao VM, Teixeira DM, Nastri CO, Martins WP: Melatonin supplementation during controlled ovarian stimulation for women undergoing assisted reproductive technology: systematic review and meta-analysis of randomized controlled trials. Fertil Steril 2014, 101:154-161. e154

166. Omu AE, Al-Azemi MK, Kehinde EO, Anim JT, Oriowo MA, Mathew TC: Indications of the mechanisms involved in improved sperm parameters by zinc therapy. Med Princ Pract 2008, 17:108-116.

167. Talevi R, Barbato V, Fiorentino I, Braun S, Longobardi S, Gualtieri R: Protective effects of in vitro treatment with zinc, $d$-aspartate and coenzyme $\mathrm{q} 10$ on human sperm motility, lipid peroxidation and DNA fragmentation. Reprod Biol Endocrinol 2013, 11:81.

168. Kotdawala AP, Kumar S, Salian SR, Thankachan P, Govindraj K, Kumar P, Kalthur G, Adiga SK: Addition of zinc to human ejaculate prior to cryopreservation prevents freeze-thaw-induced DNA damage and preserves sperm function. J Assist Reprod Genet 2012, 29:1447-1453.

169. Safarinejad MR, Safarinejad S: Efficacy of selenium and/or N-acetyl-cysteine for improving semen parameters in infertile men: a double-blind, placebo controlled, randomized study. J Urol 2009, 181:741-751.

170. Banihani S, Sharma R, Bayachou M, Sabanegh E, Agarwal A: Human sperm DNA oxidation, motility and viability in the presence of L-carnitine during in vitro incubation and centrifugation. Andrologia 2012, 44(Suppl 1):505-512.

171. Zhou X, Liu F, Zhai S: Effect of L-carnitine and/or L-acetyl-carnitine in nutrition treatment for male infertility: a systematic review. Asia Pac J Clin Nutr 2007, 16(Suppl 1):383-390.

172. Showell MG, Brown J, Yazdani A, Stankiewicz MT, Hart RJ: Antioxidants for male subfertility. Cochrane Database Syst Rev 2011, (1):CD007411. doi: 10.1002/14651858.CD007411.pub2.

173. Showell MG, Brown J, Clarke J, Hart RJ: Antioxidants for female subfertility. Cochrane Database Syst Rev 2013, 8, CD007807.

doi:10.1186/1477-7827-12-112

Cite this article as: Agarwal et al:: Utility of antioxidants during assisted reproductive techniques: an evidence based review. Reproductive Biology and Endocrinology 2014 12:112

\section{Submit your next manuscript to BioMed Central and take full advantage of:}

- Convenient online submission

- Thorough peer review

- No space constraints or color figure charges

- Immediate publication on acceptance

- Inclusion in PubMed, CAS, Scopus and Google Scholar

- Research which is freely available for redistribution 